\title{
Understanding the clinical spectrum of complicated Plasmodium vivax malaria: a systematic review on the contributions of the Brazilian literature
}

Marcus VG Lacerda ${ }^{1,2,3^{*}}$, Maria PG Mourão ${ }^{1,2,3}$, Márcia AA Alexandre ${ }^{1,2,3}$, André M Siqueira ${ }^{1,2}$, Belisa ML Magalhães ${ }^{1,2}$, Flor E Martinez-Espinosa ${ }^{1,2,4}$, Franklin S Santana Filho ${ }^{1,2}$, Patrícia Brasil ${ }^{5}$, Ana MRS Ventura ${ }^{6}$, Mauro S Tada ${ }^{7}$, Vanja SCD Couto ${ }^{8}$, Antônio R Silva ${ }^{9}$, Rita SU Silva ${ }^{10}$ and Maria GC Alecrim ${ }^{1,2,3}$

\begin{abstract}
The resurgence of the malaria eradication agenda and the increasing number of severe manifestation reports has contributed to a renewed interested in the Plasmodium vivax infection. It is the most geographically widespread parasite causing human malaria, with around 2.85 billion people living under risk of infection. The Brazilian Amazon region reports more than 50\% of the malaria cases in Latin America and since 1990 there is a marked predominance of this species, responsible for $85 \%$ of cases in 2009. However, only a few complicated cases of $P$. vivax have been reported from this region. A systematic review of the Brazilian indexed and non-indexed literature on complicated cases of vivax malaria was performed including published articles, masters' dissertations, doctoral theses and national congresses' abstracts. The following information was retrieved: patient characteristics (demographic, presence of co-morbidities and, whenever possible, associated genetic disorders); description of each major clinical manifestation. As a result, 27 articles, 28 abstracts from scientific events' annals and 13 theses/ dissertations were found, only after 1987. Most of the reported information was described in small case series and case reports of patients from all the Amazonian states, and also in travellers from Brazilian non-endemic areas. The more relevant clinical complications were anaemia, thrombocytopaenia, jaundice and acute respiratory distress syndrome, present in all age groups, in addition to other more rare clinical pictures. Complications in pregnant women were also reported. Acute and chronic co-morbidities were frequent, however death was occasional. Clinical atypical cases of malaria are more frequent than published in the indexed literature, probably due to a publication bias. In the Brazilian Amazon (considered to be a low to moderate intensity area of transmission), clinical data are in accordance with the recent findings of severity described in diverse $P$. vivax endemic areas (especially anaemia in Southeast Asia), however in this region both children and adults are affected. Finally, gaps of knowledge and areas for future research are opportunely pointed out.
\end{abstract}

Keywords: Malaria, Plasmodium vivax, Brazil, Severity, Clinical aspects, Anaemia, Systematic review

\section{Background}

Plasmodium vivax is the most geographically widespread species of Plasmodium causing human disease, with most cases reported in Central and Southeast Asia, in the horn of Africa and in Latin America [1]. It is considered to be

\footnotetext{
* Correspondence: marcuslacerda.br@gmail.com

${ }^{1}$ Fundação de Medicina Tropical Dr. Heitor Vieira Dourado, Av. Pedro

Teixeira, 25, 69040-000, Manaus Amazonas, Brazil

Full list of author information is available at the end of the article
}

a potential cause of morbidity and mortality amongst the 2.85 billion people living at risk of infection, excluding the large African populations who are mostly Duffy negative and, therefore, naturally less susceptible to this infection. However recent data suggest that the parasite is evolving and may use alternative receptors other than Duffy (DARC) for erythrocyte invasion [2]. It is estimated that $5.5 \%$ of the population under risk live in the Americas [3]. The major biological characteristic of this parasite is

\section{Biomed Central}

(c) 2011 Lacerda et al; licensee BioMed Central Ltd. This is an Open Access article distributed under the terms of the Creative Commons Attribution License (http://creativecommons.org/licenses/by/2.0), which permits unrestricted use, distribution, and reproduction in any medium, provided the original work is properly cited. 
the presence of liver hypnozoites responsible for the frequent relapses, which add a substantial number of cases to the general burden of the disease, what is being faced as one of the most challenging bottlenecks for vivax malaria eradication [4].

Although often regarded as causing a benign infection, there is recent increasing evidence that the overall burden, economic impact, and severity of $P$. vivax have been underestimated, in part due to a bias in the scientific literature which traditionally devoted most of its attention to the more lethal parasite Plasmodium falciparum, probably as a reflection of a more substantial funding [5]. Until 16 October 2011, the search in MEDLINE using $P$. vivax as keyword retrieved 5,026 indexed abstracts; using P. falciparum, on the other hand, retrieved almost five times more abstracts: 25,807. Even in places where $P$. vivax represents the major local problem to be tackled, clinical research is still focused on $P$. falciparum [6]. There is robust evidence in the past decade from hospital-based studies in India and Indonesia that $P$. vivax is able to cause severe disease $[7,8]$. Some authors argue that this clinical severity may only now be properly recognized and announced by researchers in the field, but these complications apparently are not new from a historical perspective [9]. Actually, the case fatality rate (CFR) related to malarial infections in the English marshes during the 16th and 17th centuries, corresponding to the Little Ice Age, suggest that $P$. vivax (a parasite more prone to persist in vectors even under low temperatures) may have killed part of this population already victimized by famine [10]. During the first half of the 20th century, malariotherapy in patients with neurosyphilis, using essentially the 'nonsevere' $P$. vivax parasite, led to diverse complications, CFR ranging from 3.3 to $30.3 \%$ [11]. The major related complications in these co-infected patients were liver damage, ruptured spleen, jaundice, delirium, uncontrolled vomiting and persistent headaches [11]. That reinforces the concept that $P$. vivax infection may synergize with other co-morbidities resulting in more complicated disease. Added to local geographical and social determinants, wide Annual Parasite Incidence (API) and CFR variations due to this species are seen around the world.

In summary, $P$. vivax, which has long been neglected and mistakenly considered 'benign' [12], is receiving an increasing amount of importance in the debates taking place on malaria epidemiology and control, drug resistance, pathogenesis and vaccines [13]. As reviewed elsewhere, the good clinical characterization of severe disease in vivax infection is the first step to understand how the inflammatory response to this parasite contributes to pathogenesis [14].
Traditionally, Brazil has been responsible for almost half of all cases of malaria in Latin America. In 2009, 308,498 cases of malaria were reported in this country (257,571 caused by $P$. vivax), representing $54.9 \%$ of all the malaria reported in the Americas [15]. Cases are virtually restricted to the Amazon Basin (constituted by the states of Amazonas, Acre, Roraima, Amapá, Pará, Tocantins, Rondônia, and parts of Mato Grosso and Maranhão). Amazonian urban agglomerations under continuous economical development trigger intense migration flows, such as in the city of Manaus (in the Western Brazilian Amazon), helping to maintain the disease under endemic levels [16,17]. Malaria in Brazil is mostly related to $P$. vivax since the 1990s, when the available tools for control at the moment were put together and intensified, such as the fast diagnosis through thick blood smear (TBS) in all febrile patients, and free access to anti-malarials, integrated through a decentralized primary care-centred public health system [18]. Allied to that, an active community of local malariologists has been persistently identifying the profile of anti-malarial resistance with permanent counseling to the Brazilian Ministry of Health, which responds promptly to these evidences, changing the first line regimens [19]. As the sexual forms (which are infective for the vector) of $P$. falciparum generally appear later in the course of infection, opportune diagnosis and treatment tend to have a high impact on reducing the transmission intensity of this species but the same is not true for $P$. vivax, whose gametocytes are present in the very first days of the infection, before efficacious treatment is usually started. In 2008, $59 \%$ of all malaria cases registered in the Brazilian Amazon were treated in the first $48 \mathrm{~h}$ after appearance of symptoms (SIVEP-Malaria, 2009). These public health measures allied to a regularly updated online information system also impacted the number of deaths related to P. falciparum, which were not more than 58 in 2009 (Brazilian Ministry of Health, 2010). As a consequence, even in the non-indexed literature, severity due to P. falciparum is not frequently reported anymore in Brazil.

Brazil has reported $85 \%$ of its cases related to $P$. vivax in 2010 , which puts this country in a peculiar epidemiological situation, as one of the few countries around the world with $P$. vivax predominance. The impact of $P$. vivax/P. falciparum co-infections or simultaneous circulation of both species with similar frequencies in a given population, upon the immunological status and clinical presentation of malaria is still unclear $[20,21]$, but most probably clinical data from population from certain areas should not be extrapolated to other areas in distinct epidemiological conditions. Actually, the lack of data on clinical presentation of $P$. vivax infection allied to the several particularities of this region, including the diverse genetic background of its 
population, implicate that the generalization of the findings from Southeast Asia may be inappropriate.

In Brazil, in 1903, the young physician Carlos Chagas (most known for the discovery of American trypanosomiasis afterwards) wrote his MD thesis on the haematological complications of malaria, which, at that moment, also occurred in the non-Amazon area. His major findings in studying $P$. vivax patients were severe anaemia, splenomegaly, leukopenia, cachexia and jaundice associated to concomitant staphylococcal disease [22]. Bone marrows were also analysed in these patients with no conclusive findings. Later on, during the 1940s, Djalma Batista in Manaus described a series of malarial cases from his outpatient clinics in whom large splenomegaly, cachexia and minor bleeding were frequent among those with the 'benign' tertian malaria [23]. More recently, from 1998 to 2008, 234 deaths related to vivax disease were officially reported to the Brazilian Ministry of Health [18], and an increase in the hospitalization trends for vivax patients was published in a tertiary care hospital from Manaus [24]. To complicate matters, these facts parallel a lack of robust biomarkers and specific criteria for severe disease for this species in the literature. A sine qua non requisite in the analysis of clinical severity related to $P$. vivax infection is the exclusion of mixed infection with $P$. falciparum through a more sensitive technique such as PCR and the exclusion of other co-morbidities which may be responsible for the clinical presentation per se. In the literature, in general, reports of 'complicated/severe' cases lack more precise and uniform definition criteria, in part due to the rare application of more robust endpoints such as death and admission to the intensive care unit (ICU), and therefore end up suffering bias through individual judgment of authors, editors and reviewers. As in most of the data published there were no systematic exclusion of co-morbidities and/or mono-infection confirmation using PCR, performing a meta-analysis of severe manifestations of $P$. vivax becomes virtually impossible. The other bias in the case of Brazil is that many relevant data are confined in abstracts from national scientific meetings and graduate students' dissertations and theses. The systematic review of these unpublished data therefore could contribute to the understanding of the clinical spectrum of vivax infection in this country and ultimately as a representative sample from Latin American vivax malaria.

\section{Search strategy}

The sources for published data on clinical aspects of vivax infection in Brazil were MEDLINE (1948 to February 2011) and LILACS (1982 to February 2011). The following search strategy was devised for both databases: (Plasmodium vivax).mp. AND (Brazil).mp. All types of study designs with primary data were included (cross-sectionals, case-controls, cohorts, case series and case reports). The abstracts were analysed in details by two independent reviewers and publications were selected if they mentioned any type of clinical complication (no specific criterion was used) in at least one patient with the diagnosis of vivax infection. Disagreement between the two reviewers was solved through consensus. Articles were excluded if they were reviews and also if they did not contain primary data on clinical aspects. For included studies, there were extracted data on date of publication, location, number of patients, and characteristics of participants (age range, pregnancy status, presence of co-morbidities), if molecular diagnosis through PCR was used to assess vivax malaria mono-infection and fatality. Exclusion criteria for analysis were participants with mixed infections (P. falciparum/ $P$. vivax); studies in where patients with $P$. falciparum and $P$. vivax were both presented but the clinical data reported was not individualized for each species; and studies reporting the same patients from previous studies from the same authors. Through abstract analysis, 297 articles were retrieved and after application of the inclusion and exclusion criteria, 27 articles (from 1987 to 2011) were selected, which are presented in Table 1.

Unpublished studies were searched manually in the Annals of the Congress of the Brazilian Tropical Medicine Society (published in supplements of the indexed journal Revista da Sociedade Brasileira de Medicina Tropical [Journal of the Brazilian Society of Tropical Medicine]), from 1964 to 2011. This is the most traditional scientific event for tropical medicine clinicians in Brazil. Similar inclusion and exclusion criteria were used in this search. However if the same abstract data were published afterwards as a full paper, the published paper information was presented here. If the abstract referred to a dissertation or thesis, this more detailed information was presented instead. Forty-five abstracts were retrieved from 1995 to 2011. Of these, 17 fulfilled any of the exclusion criteria and therefore, 28 abstracts are presented in Table 2.

Masters' dissertations and doctoral theses abstracts since 1987 were searched in the online database http:// capesdw.capes.gov.br/capesdw/Teses.do maintained by the Coordination for the Improvement of Higher Education Personnel (CAPES), the institution which coordinates and supervises all the Brazilian Graduate Programmes in all areas of knowledge. The full original electronic documents were downloaded from the website when available or obtained through contact with the respective graduate students. Ten dissertations and three theses are presented in Table 3.

\section{Major clinical complications}

Classical malaria paroxysms are typically short and sharply delineated within a period of less than eight hours. Fever is one feature that is almost invariably present during a paroxysm. Any of other common symptoms of 
Table 1 Summary of publications retrieved from MEDLINE and LILACS referring to clinical aspects of $P$. vivax malarial patients in Brazil (1948-2011)

\begin{tabular}{|c|c|c|c|c|c|c|c|c|c|c|}
\hline & Authors & $\begin{array}{c}\text { Year } \\
\text { of } \\
\text { publication }\end{array}$ & $\begin{array}{l}\text { Location } \\
\text { City } \\
\text { (State) }\end{array}$ & $\begin{array}{c}\text { PCR } \\
\text { confirmation }\end{array}$ & $\begin{array}{c}\text { Age } \\
\text { range } \\
\text { (in } \\
\text { years) }\end{array}$ & $\begin{array}{l}\text { Number } \\
\text { of } \\
\text { patients }\end{array}$ & $\begin{array}{l}\text { Type of clinical } \\
\text { complication }\end{array}$ & Pregnancy & Death & Co-morbidity \\
\hline 1 & $\begin{array}{c}\text { Botelho et al. } \\
{[25]}\end{array}$ & 1987 & $\begin{array}{l}\text { Cuiabá } \\
\text { (Mato } \\
\text { Grosso) }\end{array}$ & No & NA & 41 & Pulmonary manifestations & No & No & NA \\
\hline 2 & $\begin{array}{l}\text { Moura et al. } \\
\text { [26] }\end{array}$ & 1987 & NA & No & NA & 1 & Congenital malaria (?) & No & No & NA \\
\hline 3 & $\begin{array}{c}\text { Severo et al. } \\
\text { [27] }\end{array}$ & 1994 & NA & No & NA & 112 & Hepatitis and jaundice & No & No & NA \\
\hline 4 & $\begin{array}{l}\text { Marques et al. } \\
{[28]}\end{array}$ & 1996 & $\begin{array}{l}\text { São Paulo } \\
\text { (São Paulo) }\end{array}$ & No & $\begin{array}{c}5 \\
\text { weeks }\end{array}$ & 1 & $\begin{array}{c}\text { Congenital malaria and } \\
\text { anaemia }\end{array}$ & No & No & NA \\
\hline 5 & $\begin{array}{l}\text { Siqueira- } \\
\text { Batista et al. } \\
\text { [29] }\end{array}$ & 1998 & $\begin{array}{l}\text { Rio de } \\
\text { Janeiro } \\
\text { (Rio de } \\
\text { Janeiro) }\end{array}$ & No & 62 & 1 & $\begin{array}{l}\text { Cardiac arrhythmia after } \\
\text { chloroquine use }\end{array}$ & No & No & NA \\
\hline 6 & $\begin{array}{c}\text { Ventura et al. } \\
\text { [30] }\end{array}$ & 1999 & $\begin{array}{l}\text { Belém } \\
\text { (Pará) }\end{array}$ & No & $0-14$ & 100 & Anaemia & No & No & $\begin{array}{c}\text { Hookworms and } \\
\text { malnutrition }\end{array}$ \\
\hline 7 & $\begin{array}{c}\text { Pinheiro et al. } \\
\text { [31] }\end{array}$ & 2002 & $\begin{array}{l}\text { Belém } \\
\text { (Pará) }\end{array}$ & No & NA & 23 & Low birth weight & Yes & No & NA \\
\hline 8 & $\begin{array}{c}\text { Jarude et al. } \\
\text { [32] }\end{array}$ & 2003 & $\begin{array}{l}\text { Rio Branco } \\
\text { (Acre) }\end{array}$ & No & $12-49$ & 235 & $\begin{array}{c}\text { Anaemia, jaundice, } \\
\text { hepatitis and } \\
\text { hypoglycaemia }\end{array}$ & Yes & No & NA \\
\hline 9 & $\begin{array}{l}\text { Lacerda et al. } \\
\text { [33] }\end{array}$ & 2004 & $\begin{array}{c}\text { Manaus } \\
\text { (Amazonas) }\end{array}$ & Yes & 20 & 1 & ITP & No & No & No \\
\hline 10 & Silva et al. [34] & 2004 & $\begin{array}{l}\text { Belém } \\
\text { (Pará) }\end{array}$ & No & $18-60$ & 11 & $\begin{array}{l}\text { Blackwater fever after } \\
\text { primaquine use }\end{array}$ & No & No & G6PD deficiency \\
\hline 11 & $\begin{array}{l}\text { Melo et al. } \\
\quad[35]\end{array}$ & 2004 & $\begin{array}{c}\text { Manaus } \\
\text { (Amazonas) }\end{array}$ & No & $7-84$ & 126 & Ocular lesions & No & No & $\begin{array}{l}\text { Hypovitaminosis } \\
\text { A }\end{array}$ \\
\hline 12 & $\begin{array}{l}\text { Braga et al. } \\
{[36]}\end{array}$ & 2004 & $\begin{array}{c}\text { Fortaleza } \\
\text { (Ceará) }\end{array}$ & No & 25 & 1 & Neurological symptoms & No & No & NA \\
\hline 13 & $\begin{array}{l}\text { Lomar et al. } \\
{[37]}\end{array}$ & 2005 & $\begin{array}{l}\text { São Paulo } \\
\text { (São Paulo) }\end{array}$ & No & 43 & 1 & ARDS & No & No & No \\
\hline 14 & $\begin{array}{l}\text { Vermehren et } \\
\text { al. [38] }\end{array}$ & 2005 & $\begin{array}{c}\text { Manaus } \\
\text { (Amazonas) }\end{array}$ & No & 51 & 1 & Acute renal failure & No & No & No \\
\hline 15 & $\begin{array}{l}\text { Braga et al. } \\
\text { [39] }\end{array}$ & 2006 & $\begin{array}{c}\text { Coari } \\
\text { (Amazonas) }\end{array}$ & No & $14-69$ & 333 & Hepatitis & No & No & HBV \\
\hline 16 & $\begin{array}{c}\text { Cabral et al. } \\
{[40]}\end{array}$ & 2006 & $\begin{array}{c}\text { Manaus } \\
\text { (Amazonas) } \\
\end{array}$ & No & 4 & 1 & $\begin{array}{c}\text { Blackwater fever, anaemia } \\
\text { and ARDS }\end{array}$ & No & No & $\begin{array}{l}\text { Sickle cell } \\
\text { anaemia }\end{array}$ \\
\hline 17 & $\begin{array}{c}\text { Lacerda et al. } \\
{[41]}\end{array}$ & 2007 & $\begin{array}{c}\text { Manaus } \\
\text { (Amazonas) }\end{array}$ & No & 23 & 1 & Splenic hematoma & No & No & NA \\
\hline 18 & $\begin{array}{c}\text { Santana et al. } \\
{[42]}\end{array}$ & 2007 & $\begin{array}{c}\text { Manaus } \\
\text { (Amazonas) }\end{array}$ & No & $3-67$ & 73 & $\begin{array}{l}\text { Methaemoglobinemia } \\
\text { after primaquine use }\end{array}$ & No & No & G6PD deficiency \\
\hline 19 & $\begin{array}{c}\text { Lacerda et al. } \\
\text { [43] }\end{array}$ & 2008 & $\begin{array}{c}\text { Maués } \\
\text { (Amazonas) }\end{array}$ & Yes & 14 & 1 & $\begin{array}{l}\text { Chronic splenomegaly and } \\
\text { thrombocytopaenia }\end{array}$ & No & No & NA \\
\hline 20 & $\begin{array}{l}\text { Ramos Jr et al. } \\
{[44]}\end{array}$ & 2010 & $\begin{array}{c}\text { Manaus } \\
\text { (Amazonas) }\end{array}$ & No & $8-39$ & 18 & $\begin{array}{l}\text { Blackwater fever after } \\
\text { primaquine use }\end{array}$ & No & No & G6PD deficiency \\
\hline 21 & $\begin{array}{l}\text { Alexandre et } \\
\text { al. [45] }\end{array}$ & 2010 & $\begin{array}{c}\text { Manaus } \\
\text { (Amazonas) }\end{array}$ & Yes & $0-80$ & 17 & $\begin{array}{c}\text { Jaundice, anaemia, shock, } \\
\text { acute renal failure, ARDS } \\
\text { and haemoglobinuria }\end{array}$ & No & $\begin{array}{l}\text { Yes } \\
(1)\end{array}$ & $\begin{array}{c}\text { HAV, } \\
\text { hypertension } \\
\text { and diabetes }\end{array}$ \\
\hline 22 & $\begin{array}{c}\text { Siqueira et al. } \\
{[46]}\end{array}$ & 2010 & $\begin{array}{c}\text { Manaus } \\
\text { (Amazonas) }\end{array}$ & Yes & 16 & 1 & Rhabdomyolysis & No & No & No \\
\hline 23 & $\begin{array}{l}\text { Melo et al. } \\
\quad[47]\end{array}$ & 2010 & $\begin{array}{c}\text { Careiro } \\
\text { (Amazonas) }\end{array}$ & No & $5-14$ & 54 & Anaemia & No & No & $\begin{array}{l}\text { Intestinal } \\
\text { helminthes }\end{array}$ \\
\hline
\end{tabular}


Table 1 Summary of publications retrieved from MEDLINE and LILACS referring to clinical aspects of $P$. vivax malarial patients in Brazil (1948-2011) (Continued)

\begin{tabular}{cccccccc}
\hline 24 & $\begin{array}{c}\text { Andrade et al. } \\
{[48]}\end{array}$ & 2010 & $\begin{array}{c}\text { Buritis } \\
\text { (Rondônia) }\end{array}$ & Yes & $9-54$ & 19 & $\begin{array}{c}\text { Jaundice, anaemia, shock, } \\
\text { acute renal failure and } \\
\text { ARDS }\end{array}$ \\
\hline 25 & $\begin{array}{c}\text { Chagas et al. } \\
{[49]}\end{array}$ & 2010 & $\begin{array}{c}\text { Manaus } \\
\text { (Amazonas) }\end{array}$ & No & $9-44$ & 411 & $\begin{array}{c}\text { Vaginal bleeding and } \\
\text { amniorrexis }\end{array}$ \\
\hline $\begin{array}{c}\text { Fragoso et al. } \\
{[50]}\end{array}$ & 2011 & $\begin{array}{c}\text { Manaus } \\
\text { (Amazonas) }\end{array}$ & Yes & 48 & 1 & $\begin{array}{c}\text { Hypovolaemic shock after } \\
\text { CQ use }\end{array}$ \\
\hline 27 & $\begin{array}{c}\text { Ferreira et al. } \\
{[51]}\end{array}$ & 2011 & $\begin{array}{c}\text { Macapá } \\
\text { (Amapá) }\end{array}$ & No & $15-60$ & 20 & $\begin{array}{c}\text { Methaemoglobinemia } \\
\text { after primaquine use }\end{array}$ \\
\hline
\end{tabular}

Table 2 Summary of abstracts referring to clinical aspects of $\boldsymbol{P}$. vivax malarial patients published in the proceedings of the Annual Congress of the Brazilian Society of Tropical Medicine (1964-2011)

\begin{tabular}{|c|c|c|c|c|c|c|c|c|c|c|}
\hline & Authors & $\begin{array}{l}\text { Year of } \\
\text { publication }\end{array}$ & $\begin{array}{l}\text { Location } \\
\text { City } \\
\text { (State) }\end{array}$ & $\begin{array}{l}\text { PCR } \\
\text { confirmation }\end{array}$ & $\begin{array}{l}\text { Age } \\
\text { range } \\
\text { (in } \\
\text { years) }\end{array}$ & $\begin{array}{l}\text { Number } \\
\text { of } \\
\text { patients }\end{array}$ & $\begin{array}{l}\text { Type of clinical } \\
\text { complication }\end{array}$ & Pregnancy & Death & Co-morbidity \\
\hline 1 & $\begin{array}{l}\text { Alecrim et al. } \\
{[52]}\end{array}$ & 1995 & $\begin{array}{l}\text { Manaus } \\
\text { (Amazonas) }\end{array}$ & No & 26 & 2 & $\begin{array}{l}\text { Splenic haematoma } \\
\text { rupture }\end{array}$ & No & $\begin{array}{l}\text { Yes } \\
(1)\end{array}$ & NA \\
\hline 2 & $\begin{array}{l}\text { Kalmar et al. } \\
\text { [53] }\end{array}$ & 1998 & $\begin{array}{l}\text { São Paulo } \\
\text { (São Paulo) }\end{array}$ & No & 24 & 1 & $\begin{array}{l}\text { Pulmonary } \\
\text { manifestations }\end{array}$ & No & No & NA \\
\hline 3 & $\begin{array}{l}\text { Sardinha et } \\
\text { al. [54] }\end{array}$ & 1998 & $\begin{array}{l}\text { Manaus } \\
\text { (Amazonas) }\end{array}$ & No & $42 / 57$ & 2 & $\begin{array}{l}\text { Auto-immune anaemia } \\
\text { induced by secondary } \\
\text { cryoagglutinins }\end{array}$ & No & No & NA \\
\hline 4 & $\begin{array}{l}\text { Victoria et al. } \\
\text { [55] }\end{array}$ & 1998 & $\begin{array}{l}\text { Manaus } \\
\text { (Amazonas) }\end{array}$ & No & 21 & 1 & ITP & No & No & NA \\
\hline 5 & $\begin{array}{l}\text { Zumpano et } \\
\text { al. [56] }\end{array}$ & 1998 & $\begin{array}{l}\text { Belo } \\
\text { Horizonte } \\
\text { (Minas } \\
\text { Gerais) }\end{array}$ & No & 40 & 1 & $\begin{array}{l}\text { Splenic haematoma } \\
\text { rupture }\end{array}$ & No & No & NA \\
\hline 6 & $\begin{array}{l}\text { Silva et al. } \\
\text { [57] }\end{array}$ & 2000 & $\begin{array}{l}\text { Manaus } \\
\text { (Amazonas) }\end{array}$ & No & NA & 25 & $\begin{array}{l}\text { Thombocytopaenia and } \\
\text { bleeding }\end{array}$ & No & No & NA \\
\hline 7 & $\begin{array}{l}\text { Aragão et al. } \\
\text { [58] }\end{array}$ & 2001 & $\begin{array}{l}\text { Manaus } \\
\text { (Amazonas) }\end{array}$ & No & NA & 50 & $\begin{array}{l}\text { Thombocytopaenia and } \\
\text { bleeding }\end{array}$ & No & No & NA \\
\hline 8 & $\begin{array}{l}\text { Evangelista et } \\
\text { al. [59] }\end{array}$ & 2002 & $\begin{array}{l}\text { Manaus } \\
\text { (Amazonas) }\end{array}$ & No & $\begin{array}{l}<1 \\
\text { month }\end{array}$ & 7 & $\begin{array}{l}\text { Congenital malaria } \\
\text { (jaundice and anaemia) }\end{array}$ & No & No & NA \\
\hline 9 & $\begin{array}{l}\text { Moura et al. } \\
{[60]}\end{array}$ & 2002 & $\begin{array}{l}\text { Belo } \\
\text { Horizonte } \\
\text { (Minas } \\
\text { Gerais) }\end{array}$ & No & 69 & 1 & Acute lung oedema & No & Yes & NA \\
\hline 10 & $\begin{array}{l}\text { Park et al. } \\
\text { [61] }\end{array}$ & 2002 & $\begin{array}{l}\text { São Paulo } \\
\text { (São Paulo) }\end{array}$ & No & NA & 237 & Thrombocytopaenia & No & No & NA \\
\hline 11 & $\begin{array}{l}\text { Viana et al. } \\
\text { [62] }\end{array}$ & 2002 & $\begin{array}{l}\text { Santa Inês } \\
\text { (Maranhão) }\end{array}$ & No & 21 & 1 & Pleural effusion & No & No & NA \\
\hline 12 & $\begin{array}{l}\text { Albuquerque } \\
\text { et al. [63] }\end{array}$ & 2003 & $\begin{array}{l}\text { Manaus } \\
\text { (Amazonas) }\end{array}$ & No & NA & 202 & $\begin{array}{l}\text { Anaemia, } \\
\text { thrombocytopaenia, } \\
\text { blackwater fever, } \\
\text { jaundice and bleeding }\end{array}$ & No & No & $\begin{array}{l}\text { Yes (diabetes, } \\
\text { chronic renal } \\
\text { failure, HIV, G6PD } \\
\text { deficiency) }\end{array}$ \\
\hline 13 & $\begin{array}{l}\text { Lacerda et al. } \\
\text { [64] }\end{array}$ & 2003 & $\begin{array}{l}\text { Manaus } \\
\text { (Amazonas) }\end{array}$ & Yes & 46 & 1 & Acute lung oedema & No & Yes & NA \\
\hline 14 & $\begin{array}{l}\text { Silva et al. } \\
\text { [65] }\end{array}$ & 2003 & $\begin{array}{l}\text { Belém } \\
\text { (Pará) }\end{array}$ & No & 21 & 1 & Acute lung oedema & No & No & NA \\
\hline 15 & $\begin{array}{l}\text { Silva et al. } \\
\text { [66] }\end{array}$ & 2004 & $\begin{array}{l}\text { Tucuruí } \\
\text { (Pará) }\end{array}$ & No & 59 & 1 & Vasculitis & No & Yes & NA \\
\hline 16 & $\begin{array}{l}\text { Tavares et al. } \\
\text { [67] }\end{array}$ & 2004 & $\begin{array}{l}\text { Manaus } \\
\text { (Amazonas) }\end{array}$ & No & 12 & 1 & Splenic haematoma & No & No & NA \\
\hline
\end{tabular}


Table 2 Summary of abstracts referring to clinical aspects of $P$. vivax malarial patients published in the proceedings of the Annual Congress of the Brazilian Society of Tropical Medicine (1964-2011) (Continued)

\begin{tabular}{|c|c|c|c|c|c|c|c|c|c|c|}
\hline 17 & $\begin{array}{l}\text { Penna et al. } \\
\text { [68] }\end{array}$ & 2005 & $\begin{array}{l}\text { Belo } \\
\text { Horizonte } \\
\text { (Minas } \\
\text { Gerais) }\end{array}$ & No & 52 & 1 & $\begin{array}{l}\text { Pulmonary } \\
\text { manifestations }\end{array}$ & No & No & Yes (Dyslipidemia) \\
\hline 18 & $\begin{array}{l}\text { Mello et al. } \\
\text { [69] }\end{array}$ & 2006 & $\begin{array}{l}\text { Belém } \\
\text { (Pará) }\end{array}$ & No & NA & 1 & Seizures and coma & No & No & NA \\
\hline 19 & $\begin{array}{l}\text { Menezes et } \\
\text { al. [70] }\end{array}$ & 2006 & $\begin{array}{l}\text { Manaus } \\
\text { (Amazonas) }\end{array}$ & No & $14-48$ & 48 & $\begin{array}{l}\text { Abortion and } \\
\text { premature delivery }\end{array}$ & Yes & No & NA \\
\hline 20 & $\begin{array}{l}\text { Oliveira et al. } \\
\text { [71] }\end{array}$ & 2006 & $\begin{array}{l}\text { Manaus } \\
\text { (Amazonas) }\end{array}$ & No & 22 & 1 & $\begin{array}{l}\text { Blackwater fever after } \\
\text { primaquine use }\end{array}$ & No & Yes & $\begin{array}{l}\text { Yes (G6PD } \\
\text { deficiency) }\end{array}$ \\
\hline 21 & $\begin{array}{l}\text { Bastos et al. } \\
\text { [72] }\end{array}$ & 2007 & $\begin{array}{l}\text { Salvador } \\
\text { (Bahia) }\end{array}$ & No & 28 & 1 & $\begin{array}{l}\text { Jaundice and } \\
\text { cholangitis }\end{array}$ & No & No & NA \\
\hline 22 & $\begin{array}{l}\text { Campos et al. } \\
{[73]}\end{array}$ & 2007 & $\begin{array}{l}\text { São Paulo } \\
\text { (São Paulo) }\end{array}$ & No & NA & 1 & $\begin{array}{l}\text { Splenic haematoma } \\
\text { rupture }\end{array}$ & No & No & NA \\
\hline 23 & $\begin{array}{l}\text { Gurgel at al. } \\
\text { [74] }\end{array}$ & 2007 & $\begin{array}{l}\text { Manaus } \\
\text { (Amazonas) }\end{array}$ & No & $\begin{array}{l}<3 \\
\text { months }\end{array}$ & 5 & $\begin{array}{l}\text { Congenital malaria } \\
\text { (jaundice) }\end{array}$ & No & No & NA \\
\hline 24 & $\begin{array}{l}\text { Borzacov et } \\
\text { al. [75] }\end{array}$ & 2008 & $\begin{array}{l}\text { Porto } \\
\text { Velho } \\
\text { (Rondônia) }\end{array}$ & No & 33 & 1 & $\begin{array}{l}\text { Acute psychosis after } \\
\text { CQ use }\end{array}$ & No & No & NA \\
\hline 25 & $\begin{array}{l}\text { Cardoso et al. } \\
\text { [76] }\end{array}$ & 2008 & $\begin{array}{l}\text { Porto } \\
\text { Velho } \\
\text { (Rondônia) }\end{array}$ & No & 57 & 1 & Leukemoid reaction & No & No & NA \\
\hline 26 & $\begin{array}{l}\text { Ohnishi et al. } \\
{[77]}\end{array}$ & 2008 & $\begin{array}{l}\text { Belém } \\
\text { (Pará) }\end{array}$ & No & 29 & 1 & $\begin{array}{l}\text { Pulmonary } \\
\text { manifestations }\end{array}$ & No & No & NA \\
\hline 27 & $\begin{array}{l}\text { Menezes et. } \\
\text { al. [78] }\end{array}$ & 2010 & $\begin{array}{l}\text { Manaus } \\
\text { (Amazonas) }\end{array}$ & No & NA & 421 & Anaemia & Yes & No & NA \\
\hline 28 & $\begin{array}{l}\text { Ohnishi et al. } \\
\text { [79] }\end{array}$ & 2010 & $\begin{array}{l}\text { Belém } \\
\text { (Pará) }\end{array}$ & No & $>15$ & 83 & $\begin{array}{l}\text { Pulmonary } \\
\text { manifestations and TNF } \\
\text { and IL-12 } \\
\text { polymorphisms }\end{array}$ & No & No & NA \\
\hline
\end{tabular}

Table 3 Summary of master dissertations and doctoral theses retrieved from CAPES referring to clinical aspects of $P$. vivax malarial patients in Brazil (1948-2011)

\begin{tabular}{|c|c|c|c|c|c|c|c|c|c|c|}
\hline & Authors & $\begin{array}{l}\text { Year } \\
\text { of } \\
\text { publication }\end{array}$ & $\begin{array}{l}\text { Location } \\
\text { City } \\
\text { (State) }\end{array}$ & $\begin{array}{l}\text { PCR } \\
\text { confirmation }\end{array}$ & $\begin{array}{l}\text { Age } \\
\text { range } \\
\text { (in } \\
\text { years) }\end{array}$ & $\begin{array}{l}\text { Number } \\
\text { of } \\
\text { patients }\end{array}$ & $\begin{array}{l}\text { Type of clinical } \\
\text { complication }\end{array}$ & Pregnancy & Death & Co-morbidity \\
\hline 1 & $\begin{array}{l}\text { Urbaez-Brito JD } \\
\text { [80] }\end{array}$ & 1995 & $\begin{array}{l}\text { Costa } \\
\text { Marques } \\
\text { (Rondônia) }\end{array}$ & No & NA & 35 & Jaundice & No & No & $\mathrm{HBV}$ \\
\hline 2 & Alecrim MGC [81] & 2000 & $\begin{array}{l}\text { Manaus } \\
\text { (Amazonas) }\end{array}$ & Yes & $>18$ & 426 & $\begin{array}{l}\text { Thrombocytopaenia, } \\
\text { bleeding and DIC }\end{array}$ & No & $\begin{array}{l}\text { Yes } \\
(1)\end{array}$ & NA \\
\hline 3 & Neves, JJO [82] & 2002 & $\begin{array}{l}\text { Belém } \\
\text { (Pará) }\end{array}$ & No & NA & 127 & Thrombocytopaenia & No & No & NA \\
\hline 4 & Marques HO [83] & 2004 & $\begin{array}{l}\text { Manaus } \\
\text { (Amazonas) }\end{array}$ & No & $15-75$ & 106 & $\begin{array}{l}\text { Thrombocytopaenia } \\
\text { and coagulation } \\
\text { disorders }\end{array}$ & No & No & NA \\
\hline 5 & Oliveira MS [84] & 2004 & $\begin{array}{l}\text { Manaus } \\
\text { (Amazonas) }\end{array}$ & No & $0-11$ & 69 & Anaemia & No & No & $\begin{array}{l}\text { Intestinal } \\
\text { helminthes }\end{array}$ \\
\hline 6 & Silva IBA [85] & 2004 & $\begin{array}{l}\text { Belém } \\
\text { (Pará) }\end{array}$ & No & $>15$ & 83 & $\begin{array}{l}\text { Thormbocytopaenia } \\
\text { and TNF }\end{array}$ & No & No & NA \\
\hline 7 & Raposo CCBS [86] & 2006 & $\begin{array}{l}\text { Buriticupu } \\
\text { (Maranhão) }\end{array}$ & No & $1-70$ & 140 & $\begin{array}{l}\text { Jaundice, anaemia, } \\
\text { thrombocytopaenia, } \\
\text { acute renal failure, } \\
\text { ARDS, bleeding and } \\
\text { neurological symptoms }\end{array}$ & No & No & No \\
\hline
\end{tabular}


Table 3 Summary of master dissertations and doctoral theses retrieved from CAPES referring to clinical aspects of $P$. vivax malarial patients in Brazil (1948-2011) (Continued)

\begin{tabular}{|c|c|c|c|c|c|c|c|c|c|c|}
\hline 8 & Pereira MSS [87] & 2006 & $\begin{array}{l}\text { Manaus } \\
\text { (Amazonas) }\end{array}$ & No & NA & 76 & Jaundice & Yes & No & NA \\
\hline 9 & Guerreiro NSV [88] & 2006 & $\begin{array}{l}\text { Macapá } \\
\text { (Amapá) }\end{array}$ & No & $25-39$ & 35 & Anaemia & No & No & NA \\
\hline 10 & Lacerda MVG [89] & 2007 & $\begin{array}{l}\text { Manaus } \\
\text { (Amazonas) }\end{array}$ & Yes & $>18$ & 142 & $\begin{array}{l}\text { Thrombocytopaenia } \\
\text { and bleeding }\end{array}$ & No & No & No \\
\hline 11 & Silva SBR [90] & 2009 & $\begin{array}{l}\text { Cuiabá } \\
\text { (Mato } \\
\text { Grosso) }\end{array}$ & No & NA & 397 & Thrombocytopaenia & No & No & NA \\
\hline 12 & Fragoso SCP [91] & 2010 & $\begin{array}{l}\text { Manaus } \\
\text { (Amazonas) }\end{array}$ & Yes & $1-88$ & 17 & $\begin{array}{l}\text { Autopsies series (acute } \\
\text { lung oedema, shock, } \\
\text { blackwater fever, spleen } \\
\text { haematoma rupture) }\end{array}$ & No & $\begin{array}{l}\text { Yes } \\
(17)\end{array}$ & $\begin{array}{l}\text { Pneumonia, } \\
\text { G6PD } \\
\text { deficiency, } \\
\text { chronic } \\
\text { hepatitis, HIV } \\
\text { and yellow } \\
\text { fever }\end{array}$ \\
\hline 13 & Lança EFC [92] & 2011 & $\begin{array}{l}\text { Manaus } \\
\text { (Amazonas) }\end{array}$ & No & $0-14$ & 24 & $\begin{array}{l}\text { Anaemia, shock, ARDS, } \\
\text { coma, jaundice, } \\
\text { blackwater fever, } \\
\text { metabolic acidosis and } \\
\text { hypoglycaemia }\end{array}$ & No & $\begin{array}{l}\text { Yes } \\
(2)\end{array}$ & $\begin{array}{l}\text { Malnutrition, } \\
\text { gastroenteritis, } \\
\text { sepsis, G6PD } \\
\text { deficiency }\end{array}$ \\
\hline
\end{tabular}

the febrile syndrome, such as chills, rigours and sweating, are also described. These symptoms of a paroxysm could be accompanied by others, including headache, nausea and vomiting, and moderate to severe muscle, joint and back pain [93]. Indeed high fever tends to be more evident in vivax disease even with lower parasitaemia, due to its recognized lower fever-threshold (around 100 infected RBCs/microlitre) [94]. Therefore, any description of these classical symptoms, together or isolated, should be regarded by any experienced clinical as non-severe malaria, regardless of their intensity, because they are not associated to increased rates of hospitalization or fatality.

In the Brazilian literature reviewed, a wide spectrum of clinical complications aside from the classical symptoms of vivax malaria was found throughout the 68 indexed and non-indexed publications, despite the low number of deaths attributed to this species in this literature sample. The major complications are addressed as follows:

\section{Anaemia}

World Health Organization (WHO) criterion for severe anaemia is haemoglobin below $5 \mathrm{~g} / \mathrm{dL}$ in children and under $7 \mathrm{~g} / \mathrm{dL}$ in adults. However the clinical manifestations due to anaemia per se are not known and to what extent it contributes to the respiratory distress associated with the hyperdynamic status of the febrile syndrome. There is scarce literature on malarial anaemia in population-based studies in Latin America, as reviewed elsewhere [95]. On top of that, major differences in Latin America are seen when the same methodology is applied. That is probably related to distinct genetic background and environmental factors, e.g. in the Amazon Basin (intense racial mixture) and in the Colombian Pacific Coast (nonmixed black population) [96]. It is not known if anaemia is as frequent among patients from Brazil as in Southeast Asian patients, where $P$. vivax is considered to be a disease of children because the acquisition of immunity against this species occurs much faster than for $P$. falciparum, in highly endemic areas [97]. In Brazil only $25 \%$ of vivax disease affects children 0-14 years of age, however severe anaemia was reported in hospitalized children and adults, needing red blood cell (RBC) transfusions [45]. A key description of anaemia in vivax malaria children in Latin America was published in Venezuela in 2006 [98]. The 'congenital malaria' in newborns from the present series of reports with severe anaemia confirms previous findings that vivax malaria has an important clinical impact in children under 3 months [99]. Non-severe anaemia, however, seems to be as frequent as $25.8 \%$ among the population of a recent occupation area in Rondônia, where hydroelectric power plants are being built [100]. The cut-off of haemoglobin under $12 \mathrm{~g} / \mathrm{dL}$ as a criterion of anaemia however should be seen with scepticism because of age ranges and the lack of baseline levels of haemoglobin validated to specific populations, which makes meta-analyses susceptible to misclassification. Major confounding factors in the global analysis of anaemia are the local contributors to this haematological complication such as iron-deficiency anaemia, which was found to occur in 5.6\% of a rural Amazonian population, mostly among school children and women [101]. Another important associated condition, which may interfere in the comparison between distinct populations, is the prevalence of intestinal helminthic 
infection. In a study performed with anaemic children, the presence of hookworms and malnutrition was cited [30]. However some controversy exists regarding this influence since in a cohort study, children with any intestinal helminth were protected from anaemia triggered by acute vivax infection [47]. In fact anti-helminthic treatment and iron supplementation reduced the haematological indexes in the population from an endemic area for malaria [102]. No Brazilian study has addressed the concomitant diagnosis of parvovirus B19 as a contributing factor to anaemia in malaria, considering that recent evidence supports that the use of chloroquine $(\mathrm{CQ})$ may stimulate viral replication in the bone marrow, worsening anaemia [103]. Apparently pregnant women develop anaemia as a major complication in vivax infection [32,78], and the impact upon the concept needs further investigation. Chronic comorbidities affecting erythrocyte physiology, such as sickle cell anaemia (SCA), may be related to more severe haemolysis and severe anaemia as well [40].

\section{Thrombocytopaenia and other coagulation disorders}

Thrombocytopaenia as defined by platelet counts under $150,000 / \mu \mathrm{L}$ seems to be very frequent among patients with vivax malaria and apparently more frequent in vivax than in falciparum patients [104], despite not being a consensus [105]. The increase in the report of thrombocytopaenia in several reference centres could also be a reflection of a better laboratorial infrastructure. Only in recent decades in developing countries automated full blood counts included platelet count as a routine. Many studies in Brazil confirm that platelet counts are directly correlated to peripheral parasitaemia $[89,90]$, but the meaning of this finding is still unknown. However, only mild bleeding is usually associated with this haematological complication in studies where detailed and systematic clinical description of the patients was made, even for severe thrombocytopaenia, which means in general platelet count under $50,000 / \mu \mathrm{L}[81,89,90]$. In fact, there is no report in the whole literature of a fatal case of patient presenting exclusively with severe thrombocytopaenia, even for P. falciparum. That is probably why thrombocytopaenia, regardless of being described as a complication by $\mathrm{WHO}$, is not strictly-speaking considered a severity criterion by itself [106]. What happens most of the time is that thrombocytopaenia is usually taken as a surrogate marker for DIC in settings where no specific examinations to confirm this severe complication are available, such as prothrombin activation time, D-dimers and fibrin degradation products. However, there is a disproportionate difference in the proportions of thrombocytopaenia, which is considered relatively frequent in large studies for frequency estimation [90] and of DIC, which is a rare complication, very scarcely reported in the literature associated to $P$. vivax infection $[107,108]$. Actually, there is some coagulation cascade activation, but usually with minor impact on coagulation tests and platelet counts [83]. It is important to consider however that in areas where dengue is also endemic, as is the case of Brazil, thrombocytopaenia studies should obligatorily rule out this viral infection, which also presents a substantial percentage of thrombocytopaenia as part of its non-severe presentation [109]. In fact there are cases of co-infection already reported in the Brazilian Amazon recently [110], but the literature poorly describes the clinical aspects of this coincidental infection [111].

\section{Respiratory distress and pulmonary oedema}

Respiratory distress is defined by oxygen saturation less than $94 \%$, or deep breathing (acidotic breathing), or an age-stratified increased rapid respiratory rate $(>32 / \mathrm{min}$ in adults, $>40$ in children $5-14 \mathrm{y},>50$ in children aged 2 mo to $5 \mathrm{y}$, and $>60$ in babies less than $2 \mathrm{mo}$ )[112]. However this syndromic approach does not translate any mechanism of disease and may be associated to the clinical presentation of febrile syndrome during the malarial paroxysm, severe anaemia, metabolic acidosis, lung oedema, pneumonia or acute respiratory distress syndrome (ARDS). In most of the cited Brazilian studies, there are no described criteria on how respiratory distress was defined, which makes comparisons with the general literature impossible. Sometimes imprecise clinical presentation is simply defined as pulmonary manifestations. In only one, ARDS is well characterized, comprising detailed radiological characterization and arterial gas analysis $\left(\mathrm{FiO}_{2} / \mathrm{PaO}_{2}\right)$ [37]. Lung oedema is usually based on clinical and radiological parameters and the effect of fluid overload is not clear for vivax infection, since only a few cases were reported so far, Brazilian cases included [39,64,65, $113,114]$. The impairment of respiratory symptoms after the beginning of treatment with $C Q$ referred elsewhere [115] was not mentioned in any of the present reports, which could be due to inappropriate study design. Ruling out pneumonia is not easy because of the low frequency of positive blood cultures and due to the fact that in most of these patients with pulmonary complications empirical antibiotics are initiated as a rule. Data from the Papuan Indonesia indicate that many infants who die with $P$. vivax have radiological evidence of pneumonia [116], but the specificity of radiological findings to differentiate vivaxinduced pulmonary abnormalities from pneumonia is questionable. In Mozambique, pyogenic bronchopneumonia was a common cause of respiratory distress in autopsied pregnant women with falciparum malaria, in both HIV positive and negative [117]. In the Amazon, HIV prevalence is estimated to be $\sim 1 \%$ (unpublished data), which makes opportunistic diseases less prone to impact on severe clinical complications of vivax malaria, as is the case for falciparum malaria in Africa. 


\section{Neurological syndrome}

This is classically the most lethal clinical complication of severe falciparum malaria and the definition is also very imprecise with a wide spectrum of possible presentations, such as: impaired consciousness or unrousable coma (Glasgow coma score $\leq 10$ or Blantyre coma scale $\leq 2$ ); prostration, i.e. generalized weakness so that the patient is unable walk or sit up without assistance; failure to feed; or multiple convulsions (more than two episodes in $24 \mathrm{~h}$ ). Despite being infrequent in our studies, the phenomenon was also reported but not only in children $[36,86]$. These reports must be very cautious in terms of ruling out other malarial complications as the cause of the neurological manifestations, such as hypoglycaemia and metabolic acidosis, but also associated infections as bacterial or viral meningoencephalitis. In India, acute intermittent porphyria was an unexpected co-morbidity associated to the neurological manifestations of patients with vivax malaria [118]. In Papua, P. vivax-associated coma was rare, occurring 23 times less frequently than that seen with falciparum malaria, and was associated with a high proportion of non-malarial causes and mixed infections detected using PCR [119].

\section{Acute renal failure}

This complication is suspected in cases of oliguria and confirmed if serum creatinine is higher than $3.0 \mathrm{mg} / \mathrm{dL}$. Bacterial sepsis, dehydration, shock and past history of chronic renal failure should be routinely searched in the differential diagnosis. It was also reported in the Brazilian literature $[38,48]$, but in one study one case was found in a patient with arterial hypertension, what could be a triggering condition [45]. Despite not being frequent in Brazil, Plasmodium malariae is found in some scattered areas [120], and as a potential cause of glomerulonephritis [121], this parasite should be ruled out by molecular biology tools whenever acute renal failure is detected in a malarial patient with vivax infection, due to similarities of these two species at routine optical microscopy.

\section{Jaundice}

New WHO guidelines already point to hyperbilirubinaemia (total bilirubin $>3.0 \mathrm{mg} / \mathrm{dL}$ ) as being a weak marker of severity, unless it is followed by any other vital organ dysfunction [106]. This finding seems to be the most frequent among children and adults with vivax disease considered as 'severe' $[122,123]$. Since haemolysis is not usually as severe as to cause significant clinical jaundice, most of these patients actually have some hepatocyte necrosis as evidenced by the mild to moderate liver enzymes (AST/ALT) increase with subsequent cholestasis [124]. It was shown that icteric syndrome was a common cause of hospitalization in pregnant women with vivax malaria in Manaus [87]. It was also detected in newborns $[59,74]$, which makes vivax malaria an obligatory differential diagnosis of neonatal sepsis. Jaundice in the presence of vomiting and upper abdominal pain should raise suspicion on acalculous cholecystitis, a poorly described complication apparently with good prognosis [125]. Other diseases that may evolve to an icteric syndrome may be ruled out, especially because they are also more frequent in the tropics, such as leptospirosis [34] and typhoid fever [126,127]. Hepatitis A virus (HAV) and vivax co-infection has already been reported as cause of jaundice and high elevation of transaminases [45]. Hepatitis B virus (HBV) is also highly prevalent in Brazil, especially in the Amazon [128] and there is some evidence that $P$. vivax/HBV co-infection may be related to more frequent jaundice [80] and higher transaminase levels.

\section{Algid malaria}

Algid malaria refers to the shock syndrome usually defined as circulatory collapse (systolic pressure under $70 \mathrm{mmHg}$ in adults or under $50 \mathrm{mmHg}$ in children) non-responsive to fluids. In the present vivax malaria reports, it was more reported most frequently among patients who died, suggesting that, as expected for this severe clinical complication, it could be regarded as a good marker of severity. However, the aetiology of this complication is still unclear even for P. falciparum. Apparently it is multifactorial and the complication should be regarded as a syndrome where cardiac dysfunction, dehydration, bleeding, adrenal insufficiency, and bacterial sepsis could all play a role [129]. A review of all malaria deaths in the USA found that $5 \%$ were due to $P$. vivax associated with cardiac disease [130], which suggests cardiac dysfunction as a contributing factor to algid malaria. There is robust evidence that bacteraemia in Africa is associated with higher fatality in falciparum malaria in children [131]. Less frequently shock occurs isolated, but usually as part of multi-organ dysfunction syndrome (MODS), leading to a clinical picture suggestive of 'malaria-induced toxic shock' [132].

\section{Metabolic complications}

Metabolic acidosis (plasma bicarbonate $<15 \mathrm{mmol} / \mathrm{L}$ ) and hyperlactataemia (lactate $>5 \mathrm{mmol} / \mathrm{L}$ ), which are common in severe falciparum malaria and are good predictors of fatal outcome, have never been described in vivax severe disease. In a series of children with vivax infection admitted to the ICU, metabolic acidosis is mentioned [92], however concomitant sepsis is described in this series and specificity for malaria cannot be assumed. If one admits lactic acidosis as a consequence of hypoxia triggered by microvasculature obstruction in falciparum disease, the scarcity of data on the frequency of this phenomenon in vivax disease may simply reflect the less severe obstruction due to less cytoadhesion, as already suggested elsewhere 
$[133,134]$. In the case of hypoglycaemia (blood glucose < $40 \mathrm{mg} / \mathrm{dL}$ ), the complication has been rarely described elsewhere [123,135], and in only two studies in Brazil this finding was reported among children and pregnant women [32,92].

\section{Pregnancy-associated malaria}

The impact of vivax infection upon pregnancy and the concept is less clear in Brazil and Latin America as a whole, despite robust evidence that vivax malaria causes low birth weight and maternal anaemia exists in Thailand [136] and Indonesia [137]. The burden of the infection due to this species in Brazilian pregnant women from a highly endemic area in the Amazon seems to be high [138]. Malaria anaemia in pregnant women with vivax is already known [137] and data from Brazil confirm that this is the most common complication among these women [78]. Additionally the few reports in the present series also point to low birth weight, vaginal bleeding, amniorrhexis, abortion, premature delivery, hypoglycaemia, hepatitis and jaundice as complications [31,32,49, $70,87]$. Hyperemesis gravidarum may superimpose to the febrile syndrome and to the gastrointestinal side effects associated to CQ in pregnant women, contributing to uncontrolled vomiting and consequent metabolic disorders. Apparently in the case of pregnancy, co-morbidities do not seem to be frequent among patients with clinical complications. Despite the need of more pathogenesis studies with the infected placenta, ultrasound studies in order to search for prognostic markers are urgently needed.

\section{Atypical complications}

Some atypical complications are not frequently described for malaria and likewise are not classically referred as severe malaria. Rhabdomyolysis has been reported for vivax in 1993 in a patient with myoadenylate deaminase deficiency [139]; only one case was reported in Brazil in a patient without co-morbidities [46]. Rarely, patients with vivax malaria could evolve with immune thrombocytopenic purpura (ITP) as a complication of the acute infection [33]. To confirm this diagnosis, the patient has to be followed up with persistent thrombocytopaenia for many weeks after the efficacious anti-malarial treatment and diseases, in which ITP is more frequently seen, such as HIV, should be discarded. The mechanisms involved are poorly understood. Splenomegaly is considered a typical finding in the physical examination of a patient with vivax disease, but the occurrence of spleen haematomas evolving with rupture and fatal outcome is relatively rare $[41,52,91]$ despite being more frequent among this species as compared to falciparum [140]. In any case, patients with vivax malaria referring abdominal pain should be investigated for this complication as some patients may evolve with a bad prognosis if not properly managed by a surgeon.
Ocular manifestations in vivax disease apparently have no relation to cerebral malaria or bad prognosis, as is the case for falciparum [141]. Few reports have been published on vivax patients with non-severe disease and retinal haemorrhage [142] and in Brazil this fundoscopical finding was associated with hypovitaminosis A [35]. Another atypical complication, which may be more frequent than expected for vivax infection, and with outstanding impact upon the development of some emerging economies in the globe, is poor school performance which should be a surrogate marker for the intellectual impairment related to malaria [143]. Acute malnutrition has been shown to be a complication of vivax malaria in highly endemic areas [144]. In Brazil a few evidences show that malnourishment and vivax co-exist but the impact of this association is still unknown [145]. In only two studies was malnutrition referred to as a possible cause of the reported clinical complication [92,146]. Vasculitis [66], leukemoid reaction [76] and pleural effusion [62] as a marker of severity seems to be speculative and details of these reports do not support any in-depth analysis.

\section{Other aspects}

High parasite density as a marker of severity for $P$. vivax, as it is for $P$. falciparum, still needs additional studies, considering this parasite infects preferably reticulocytes. The same occurs with the presence of schizonts in peripheral blood, which is usually associated with high sequestered biomass and severity for falciparum [147], but is still an unexplored aspect for vivax. Strong linear trends were identified regarding increasing plasma levels of $C$ reactive protein (CRP) and the gradation of disease severity [48]. Super-oxide dismutase-1 (SOD-1) seems to be a powerful predictor of disease severity in individuals with different clinical presentations of vivax malaria [148].

As soon as precise markers of severity are available, it would be possible to design studies powered to analyse the influence of the host genetics in the development of severe vivax disease. Some association between pulmonary manifestations and TNF and IL-12 polymorphisms has been attempted [79]. It has been proposed for the first time in Manaus that G6PD deficiency could protect against vivax malaria, in a cross-sectional study, based on past history of the enrolled population [149]. This protection was later confirmed in Pakistan [150]. Male hemizygotes for this deficiency also showed to be protected against severe falciparum malaria [151]. No data exist on the protection against severe vivax disease. Likewise, people with the FYA/FYB genotype presented higher susceptibility to clinical vivax malaria [152]. Since the discovery in Brazil that Duffy-negative individuals could be infected by $P$. vivax [153], some speculation on the other possible invasion receptors has emerged. However, cohort studies are needed to investigate the real impact of the distinct Duffy 
genotypes on clinical malaria incidence, submicroscopic asymptomatic infection, malaria-triggered anaemia and lower parasitaemia, as already suggested for FYB/FYX and FYA/FYX genotypes in the Brazilian Amazon [154].

\section{Advances in pathogenic mechanisms}

The major advance in the study of the pathogenesis of severe vivax disease was the demonstration of $P$. vivaxinfected RBCs cythoadhesion on human lung endothelial cells (HLEC) and placental tissue ex vivo [134]. This cythoadhesion was obviously lower than P. falciparuminfected RBCs adhesion, but with similar stability. However the next challenge is to try to link this finding to the in vivo phenomena [155]. The increased adhesion with the addition of LPS in the P. vivax ex vivo model suggests that endothelial activation may be an enhancing event. The role of augmented platelet-derived microparticles [156] and $\mathrm{CD}^{+}{ }^{+} \mathrm{CD} 25^{+} \mathrm{FoxP}^{+}$regulatory $\mathrm{T}$ cells (Tregs) cells found in vivax disease should also be investigated in severe disease. Plasma levels of TNF, IFN- $\gamma$ and also IFN- $\gamma / \mathrm{IL}-10$ ratios were increased and exhibited a linear trend with gradual augmentation of disease severity [48]. Patients with severe disease also presented higher haemolysis and higher plasma concentrations of $\mathrm{Cu} / \mathrm{Zn}$ SOD-1 and lower concentrations of PGE-2 and TGF- $\beta$ than those with mild disease [157]. Oxidative stress was also proposed as a mechanism for thrombocytopaenia found in vivax disease $[158,159]$, as well as its association with TNF [85]. Circulating immune complexes were not associated to vivax thrombocytopaenia [89], but polymorphisms of the highly immunogenic AMA-1 were associated to platelet count in these patients [160], suggesting that immunological mechanisms are involved in platelet destruction. In the case of anaemia, there is no correlation between the presence of anti-erythrocyte and anti-cardiolipin antibodies and the presence or intensity of this haematological finding [161]. Auto-immunity induced by secondary cryoagglutinins should be explored [54]. Erythropoiesis seems to be affected [162], and the finding of parasites inside the bone marrow [43] stimulate the search for mechanisms of diserythropoiesis in this milieu, despite technical limitations to analyse this tissue in humans. The role of the spleen in severe disease is still unknown, as well as the role of the variant subtelomeric multigene vir family, which may influence the sequestration of infected RBCs in this organ [163]. Parasite genetics, such as MSP-1 and CSP polymorphisms, has not been shown to be associated with clinical severity [164].

In summary, the immune response in patients with severe vivax disease has not been fully addressed in the general literature, and further approaches are needed in order to unveil immune mechanisms related to these complications.

\section{Vivax malaria therapy concerns}

In terms of therapy, CQ and primaquine (PQ) are still the drugs of choice for the treatment of vivax malaria in many endemic areas, Brazil included. It is important however to keep in mind that side effects of these drugs could be erroneously taken as clinical severity associated to the parasite infection. In the case of CQ, it is considered a safe drug, despite the occurrence of pruritus, which most of the time is considered to be a minor effect and rarely requires the drug withdrawal [165]. Psychosis on the other hand is a more severe complication $[75,166]$, as well as cardiac arrhythmia [29]. Atypical complications of its use such as severe gastric bleeding were associated with haemophilia A [50]. In the case of $\mathrm{PQ}$, tranquillity is not the same as with CQ, because PQ is able to induce metahaemoglobinaemia [42,51] and severe haemolysis [44] in patients with G6PD deficiency. The burden of the deficiency in Brazil is poorly measured but the few data available in endemic areas for malaria has shown it to be between 3.0\% [149] and 5.8\% [167] among men, since the deficiency is linked to the X-chromosome. In the case of Brazil, the prescription of PQ in the abbreviated regimen $(0.5 \mathrm{mg} / \mathrm{kg} /$ day for 7 days $)$ without any routine G6PD screening may contribute to increase the frequency and severity of the side effects triggered by this drug, as confirmed by the reports of patients with blackwater fever after PQ use, including one fatal case $[63,71,91,92,168]$. To complicate matters, for the radical cure, the new drug under late stage clinical investigation, tafenoquine, shows no evidence that it is safer than PQ in G6PD deficient [169].

The simultaneous occurrence of severe vivax disease and CQ-resistance in some countries has raised the question of a possible association between severity and resistance, especially for anaemia [170]. CQ resistance actually has been reported in Brazil almost at the same time as clinical severity $[171,172]$, but some studies argue against that, showing that severe patients responded to CQ [45]. Added to that, reliable genetic markers of resistance are lacking [173]. Increased levels of $p v m d r-1$ and pvcrt-o RNA in a single severe patient with vivax malaria however paved the way to the study of gene expression in association to resistance [174].

As suggested by the present data, 11 cases were reported in Brazilian travellers who live in the non-endemic area and occasionally go to the Amazon. Regarding the possibility of severe disease triggered by $P$. vivax, Travel Outpatient Clinics should emphasize to their clients the possible complications of this disease, still considered 'benign' in most of the educational folders and travellers' guides, especially because no good chemoprophylaxis against relapses related to this species is available to date. On top of that, retarded diagnosis and treatment outside the Amazon area contributes to the higher fatality rate of 
P. falciparum patients [18]. A similar situation could be observed for $P$. vivax, being this disease misdiagnosed as other febrile diseases.

Despite the increasing evidence of CQ-resistance worldwide, the Brazilian Ministry of Health still recommends CQ as the first line therapy for vivax treatment, considering that only one single study has properly shown $\sim 10 \%$ of resistance in the area of Manaus [172]. The few available efficacy studies on ACT for the treatment of vivax were reviewed recently [175], and give good evidence for their use in vivax malaria, however, more studies are needed. Only recently the Brazilian Ministry of Health followed the WHO recommendations to manage vivax severe patients with parenteral artemisinin derivatives as if they had severe falciparum infection, considering that a submicroscopic mixed infection could be misdiagnosed in the routine TBS [106]. This recommendation was already stated by the famous Brazilian parasitologist Samuel Pessôa in his Medical Parasitology textbook, from 1967 [176]. Supportive therapy is even more neglected and there is virtually no study focusing in the clinical management of patients with severe vivax disease.

\section{Research priorities}

There are actually many priorities in clinical research related to vivax disease. The major ones were discussed previously. Considering that asymptomatic infections due to $P$. vivax are even more common in endemic areas for both species [177], the likelihood of an asymptomatic patient becoming ill due to another microorganism is not improbable, which requests a good epidemiological characterization of the endemic area where the severe cases are being reported and systematic exclusion of mixed infections through PCR, due to the possibility of submicroscopic infection with $P$. falciparum. Another major priority in vivax research is the investigation of concurrent infections through systematic laboratory exclusion of the most prevalent infectious diseases in severe patients. In Figure 1, the major research questions are addressed.

\section{Conclusions}

In the present systematic review, the major limitation was the fact that most of the information was retrieved from non-peer reviewed sources. However, it seems clear that vivax patients in Brazil are calling the attention of their physicians only recently. Like other infectious diseases, defining severity criteria is a major challenge. As an example, dengue fever specialists have defined 'warning signs' for dengue haemorrhagic fever, the most lethal complication of the infection due to dengue virus, which are early signs that should raise the suspicion of severe dengue but are not applied themselves to the final classification [178] as proper intervention can avoid the patient evolving to more severe stages. Sometimes in the literature potential 'warning signs' for severe vivax malaria are mistaken for severity criteria, which are those ultimately related to increased fatality. WHO severity criteria formerly developed for falciparum disease seem to apply reasonably to vivax disease as well, but there are clearly 'warning signs' that should motivate clinicians from the tropics to observe patients more closely, such as isolated thrombocytopaenia, isolated jaundice or the presence of chronic or acute co-morbidities. For example, during influenza outbreaks, the virus does not necessarily kill per se, but compromises the most vulnerable population and facilitates fatal secondary bacterial infections. The most common complications observed in the field are not necessarily the most frequently reported in the literature, sometimes biased by the uniqueness or exoticness of the cases reported. It is only after 1987 that these cases started to be reported in Brazil in indexed and nonindexed publications, which may simply parallel the increase in the absolute numbers of vivax cases in Brazil, culminating in the more frequent observation of rare clinical events triggered by this parasite. Publication bias may also impact the chronology of these complicated case reports, especially when research group leaderships based in the endemic areas start to look for clinical aspects more closely. It is noteworthy however that studies on pathogenesis must be careful when dealing with severe vivax disease as a single entity. The best approach is to study groups of patients with specific complications (e.g., severe anaemia or ARDS) in order to minimize the risk of heterogeneous groups with probable multifactor causality, including the diversity of host genetics. The amount of complications related to anti-malarial drug use is not negligible, especially primaquine. Multicentric studies using standard protocols, with the proper care of confirming mono-infection by more specific tools (e.g. PCR) and ruling out co-morbidities, are urgently needed to characterize the real spectrum of vivax disease worldwide. Tissues from deceased patients are also waited, in order to support more robust analyses of the mechanisms of death. Without that information, vaccine clinical trials against $P$. vivax will not be able to include among their endpoints the protection against the severe disease (essentially severe anaemia), which parallels the frequency of severe falciparum anaemia in some endemic areas. The recent discussion on malaria eradication will only succeed if the two parasites which most affect humans begin to be treated as distinct and not causing a single disease. Clinical characterization is the first step to estimate its burden and ultimately to plan any control strategy in the near future. 


\section{Epidemiology}

1. What is the real incidence of severe disease in populationbased studies in Latin America?

2. Is the incidence of severe disease similar in distinct epidemiological scenarios? And what is the impact of the health system organization on this severity?

3. What is the prognosis and fatality rate of severe disease in hospitalized and non-hospitalized patients?

4. What is the role of host genetics (e.g. Duffy genotypes, G6PD deficiency) upon severity?

\section{Clinical aspects}

1. Do the WHO criteria for severe $P$. falciparum malaria also apply for $P$. vivax severe disease?

2. Which clinical complications are able to predict death?

3. What is the contribution of co-morbidities to severe disease?

4. What is the contribution of concurrent infections (bacterial, viral, fungal, parasitic) to severe disease?

5. Are there specific severity presentation in some groups, e.g. pregnant women and children?

6. Which are the bad prognostic findings in obstetric ultrasounds in pregnant women with malaria?

7. What is the burden of clinical complications related more to drugs' side effects?

\section{Pathogenesis}

1. Which are the microscopic findings of autopsies from patients who died with the diagnosis of vivax infection?

2. Do all the clinical complications, classified as 'severe', share the same mechanisms of disease?

3. Is severe disease linked to the existing evidence of ex vivo cytoadhesion of $P$. vivax infected RBCs? What triggers endothelial activation?

4. Which are the best biomarkers for severity?

\section{Therapeutic aspects}

1. Is clinical severity linked to CQ-resistance?

2. What should be the standard-of-care specific treatment for severe patients in areas where CQ-resistance is not high?

3. Antibiotics should be used systematically in which severe complications?

4. What type of adjunctive treatment should be initiated?

Figure 1 Major research priorities in the study of severe vivax disease.

\section{Abbreviations}

ACT: Artemisinin-Combination Therapy; AMA: Apical Membrane Antigen; API: Annual Parasite Incidence; ARDS: Acute Respiratory Distress Syndrome; CAPES: Coordination for the Improvement of Higher Education Personnel;

CQ: Chloroquine; CRP: C-Reactive Protein; CSP: Circumsporozoite Protein;

DIC: Disseminated Intravascular Coagulation; G6PD: Glucose-6-Phosphate-
Dehydrogenase; HAV: Hepatitis A Virus; HBV: Hepatitis B Virus; HLEC: Human Lung Endothelial Cell; ICU: Intensive Care Unit; IL: Interleukin; INF: Interferon; ITP: Immune Thrombocytopenic Purpura; MODS: Multi-Organ Dysfunction Syndrome; MSP: Merozoite Surface Protein; PCR: Polymerase-Chain Reaction; PQ: Primaquine; RBC: Red Blood Cell; SCA: Sickle Cell Anaemia; SIVEP-Malaria: Epidemiological Surveillance Information System for Malaria; SOD: 
Superoxide dismutase; TBS: Thick Blood Smear; TGF: Tumor Growth factor; TNF: Tumor Necrosis Factor

\section{Acknowledgements}

We acknowledge the organizers of the 47th Congress of the Brazilian Society of Tropical Medicine, held in Natal (Rio Grande do Norte) on 23-26 March, 2011, especially its President Dr. Kleber Luz, for embracing and supporting the 1st Brazilian Workshop on Severe P. vivax as part of its official programme from whose reflections this review was written. The workshop was supported by the PRONEX Malaria Network, funded by the Brazilian Ministry of Science and Technology (MCT), National Council for Scientific and Technological Development (CNPq), Brazilian Ministry of Health (DECIT/ SCTIE/MS) and the Research Support Foundations from the states (FAPEAM, FAPERJ, FAPESP, FAPEPA, FAPEMAT, FAPEMIG). MVGL is a level 2 productivity fellow from CNPq.

\section{Author details}

${ }^{1}$ Fundação de Medicina Tropical Dr. Heitor Vieira Dourado, Av. Pedro Teixeira, 25, 69040-000, Manaus Amazonas, Brazil. ${ }^{2}$ Universidade do Estado do Amazonas, Av. Pedro Teixeira, 25, 69040-000, Manaus Amazonas, Brazil. ${ }^{3}$ Universidade Nilton Lins, Av. Prof. Nilton Lins, 3259, 69058-040, Manaus Amazonas, Brazil. ${ }^{4}$ Instituto Leônidas e Maria Deane, FIOCRUZ Amazônia, R. Terezina, 476, 69057-070, Manaus Amazonas, Brazil. ${ }^{5}$ Fundação Oswaldo Cruz, Av. Brasil, 4365, 21040-360 Rio de Janeiro, Brazil. 'Instituto Evandro Chagas, Rodovia BR-316 km 7 s/n, 67030-000 Ananindeua, Brazil. ${ }^{7}$ Instituto de Pesquisas em Patologias Tropicais, R. da Beira, 7671, Rodovia BR-360 km 3, Porto Velho, Rondônia, Brazil. ${ }^{8}$ Secretaria de Saúde do Amapá, Av. FAB, 69, 68.900-000 Macapá, Amapá, Brazil. ' Universidade Federal do Maranhão, Praça Madre Deus 2, 65025-560, São Luiz Maranhão, Brazil. ${ }^{10}$ Universidade Federal do Acre, Rodovia BR-364 km 4, 6637, 69915-900, Rio Branco Acre, Brazil.

\section{Authors' contributions}

MVGL and MGCA conceived the review. MAAA performed the bibliographical research and retrieved the references. MVGL drafted the manuscript. MPGM, AMS, BMLM, FEME, FSSF, PB, AMRSV, MST, VSCDC, ARS and RSUS critically revised the document. All authors read and approved the final manuscript.

\section{Competing interests}

The authors declare that they have no competing interests.

Received: 20 October 2011 Accepted: 9 January 2012

Published: 9 January 2012

\section{References}

1. Mendis K, Sina BJ, Marchesini P, Carter R: The neglected burden of Plasmodium vivax malaria. Am J Trop Med Hyg 2001, 64:97-106.

2. Mendes C, Dias F, Figueiredo J, Mora VG, Cano J, de Sousa B, do Rosario VE, Benito A, Berzosa P, Arez AP: Duffy negative antigen is no longer a barrier to Plasmodium vivax-molecular evidences from the African West Coast (Angola and Equatorial Guinea). PLoS Negl Trop Dis 2011, 5:e1192.

3. Guerra CA, Howes RE, Patil AP, Gething PW, Van Boeckel TP, Temperley WH, Kabaria CW, Tatem AJ, Manh BH, Elyazar IR, Baird JK, Snow RW, Hay SI: The international limits and population at risk of Plasmodium vivax transmission in 2009. PLoS Negl Trop Dis 2010, 4:e774.

4. Mueller I, Galinski MR, Baird JK, Carlton JM, Kochar DK, Alonso PL, del Portillo HA: Key gaps in the knowledge of Plasmodium vivax, a neglected human malaria parasite. Lancet Infect Dis 2009, 9:555-566.

5. Price RN, Tjitra E, Guerra CA, Yeung S, White NJ, Anstey NM: Vivax malaria: neglected and not benign. Am J Trop Med Hyg 2007, 77:79-87.

6. Lacerda MVG, Zackiewicz C, Alecrim WD, Alecrim MGC: The neglected Plasmodium vivax: are researchers from endemic areas really concerned about new treatment options? Rev Soc Bras Med Trop 2007, 40:489-490.

7. Kochar DK, Saxena V, Singh N, Kochar SK, Kumar SV, Das A: Plasmodium vivax malaria. Emerg Infect Dis 2005, 11:132-134.

8. Tjitra E, Anstey NM, Sugiarto P, Warikar N, Kenangalem E, Karyana M, Lampah DA, Price RN: Multidrug-resistant Plasmodium vivax associated with severe and fatal malaria: a prospective study in Papua, Indonesia. PLoS Med 2008, 5:e128.

9. Rogerson SJ, Carter R: Severe vivax malaria: newly recognised or rediscovered. PLoS Med 2008, 5:e136.
10. Reiter P: From Shakespeare to Defoe: malaria in England in the Little Ice Age. Emerg Infect Dis 2000, 6:1-11.

11. Austin SC, Stolley PD, Lasky T: The history of malariotherapy for neurosyphilis. Modern parallels. JAMA 1992, 268:516-519.

12. Picot S: Is Plasmodium vivax still a paradigm for uncomplicated malaria? Med Mal Infect 2006, 36:406-413.

13. Galinski MR, Barnwell JW: Plasmodium vivax: who cares? Malar J 2008, 7(Suppl 1):S9.

14. Bassat Q, Alonso PL: Defying malaria: Fathoming severe Plasmodium vivax disease. Nat Med 2011, 17:48-49.

15. WHO: World Malaria Report 2010. 2010.

16. Saraiva MG, Amorim RD, Moura MA, Martinez-Espinosa FE, Barbosa MG: Urban expansion and spatial distribution of malaria in the municipality of Manaus, State of Amazonas. Rev Soc Bras Med Trop 2009, 42:515-522.

17. Gonçalves MJF, Alecrim WD: Non-planed urbanization as a contributing factor for malaria incidence in Manaus-Amazonas, Brazil. Rev Salud Publica (Bogota) 2004, 6:156-166.

18. Oliveira-Ferreira J, Lacerda MV, Brasil P, Ladislau JL, Tauil PL, DanielRibeiro CT: Malaria in Brazil: an overview. Malar J 2010, 9:115.

19. Gama BE, Lacerda MV, Daniel-Ribeiro CT, Ferreira-da-Cruz MF: Chemoresistance of Plasmodium falciparum and Plasmodium vivax parasites in Brazil: consequences on disease morbidity and control. Mem Inst Oswaldo Cruz 2011, 106(Suppl 1):159-166.

20. Genton B, D'Acremont V, Rare L, Baea K, Reeder JC, Alpers MP, Muller I: Plasmodium vivax and mixed infections are associated with severe malaria in children: a prospective cohort study from Papua New Guinea. PLOS Med 2008, 5:e127.

21. Maitland K, Williams TN, Bennett S, Newbold Cl, Peto TE, Viji J, Timothy R, Clegg JB, Weatherall DJ, Bowden DK: The interaction between Plasmodium falciparum and P. vivax in children on Espiritu Santo island, Vanuatu. Trans R Soc Trop Med Hyg 1996, 90:614-620.

22. Chagas C: Hematological studies of impaludism. MD Thesis Manguinhos Institute; 1903.

23. Batista D: The paludisme in the Amazon: a contribution to epidemiology protozoology and clinics, study about the billiary-hemoglobinuric fever. Rio de Janeiro: Imprensa Nacional; 1946.

24. Santos-Ciminera PD, Roberts DR, Alecrim MG, Costa MR, Quinnan GV Jr: Malaria diagnosis and hospitalization trends, Brazil. Emerg Infect Dis 2007, 13:1597-1600.

25. Botelho C, Guedes Barbosa LS, Aquino JL, Silva MD, Meirelles SM, Jardim JR: Respiratory manifestations in Plasmodium falciparum and vivax malaria. Rev Inst Med Trop Sao Paulo 1987, 29:337-345.

26. Moura EFA, Kawachi J, Mattos MNR, Cavalcante RS, Duarte AN: Neonatal malaria: report of a case. J Pediatr (Rio J) 1987, 62:279-280

27. Severo V, Severo MMS, Behar PR, Dossin TJ: Laboratory profile of malarial patients. J Bras Med 1994, 67:141-154.

28. Marques HH, Vallada MG, Sakane PT, Boulos M: Congenital malaria: case reports and brief review of literature. J Pediatr (Rio J) 1996, 72:103-105.

29. Siqueira-Batista R, Ramos AN Jr, Pessanha BS, Sforza-de-Almeida MP, Potsch DF: Chloroquine and cardiac arrhythmia: case report. East Afr Med J 1998, 75:117-119.

30. Ventura AMRS, Pinto AYN, Silva RSU, Calvosa VSP, Silva Filho MG, Souza JM: Plasmodium vivax malaria in children and adolescents - epidemiological, clinical and laboratory features. J Pediatr (Rio J) 1999, 75:187-194.

31. Pinheiro MCN, Branco E, Barata ACS, Dantas RTS, Fernandes WCS: Malaria during the pregnancy and low birth weight from endemic areas in the Amazon. Rev Para Med 2002, 16:25-28.

32. Jarude R, Trindade R, Tavares-Neto J: Malaria in pregnant women of a public maternity of Rio Branco (Acre State, Brazil). Rev Bras Ginecol Obstet 2003, 25:149-154

33. Lacerda MV, Alexandre MA, Santos PD, Arcanjo AR, Alecrim WD, Alecrim MGC: Idiopathic thrombocytopenic purpura due to vivax malaria in the Brazilian Amazon. Acta Trop 2004, 90:187-190.

34. Srinivas R, Agarwal R, Gupta D: Severe sepsis due to severe falciparum malaria and leptospirosis co-infection treated with activated protein $\mathrm{C}$. Malar J 2007, 6:42

35. Melo AM, de Carvalho RA, Figueiredo JF, Vannucchi H, Jordao A Jr, Rodrigues ML: Serum vitamin A levels in patients with ocular lesions attributable to non-complicated malaria in the Brazilian Amazon region. Trans R Soc Trop Med Hyg 2004, 98:485-488. 
36. Braga MD, Alcantara GC, Silva CN, Nascimento CG: Cerebral malaria in Ceara: a case report. Rev Soc Bras Med Trop 2004, 37:53-55

37. Lomar AV, Vidal JE, Lomar FP, Barbas CV, Matos GJ, Boulos M: Acute respiratory distress syndrome due to vivax malaria: case report and literature review. Braz J Infect Dis 2005, 9:425-430.

38. Vermehren R, Cardoso AD, Bulbol WS, Franco M, Coelho K, Lorenzi F, Nunes V, Gonçalves J: Report of a case of acute renal failure in Plasmodium vivax malaria. J Bras Nefrol 2005, 27.

39. Curlin ME, Barat LM, Walsh DK, Granger DL: Noncardiogenic pulmonary edema during vivax malaria. Clin Infect Dis 1999, 28:1166-1167.

40. Cabral PHO, Andrade SD, Alecrim WD, Alecrim MGC, Lacerda MVG: Malaria and sickle cell anemia: report of complications and clinical management of three patients in a highly endemic area for Plasmodium vivax malaria in the Brazilian Amazon. Case Rep Clin Pract Rev 2006, 7:220-223.

41. Lacerda MVG, Oliveira SL, Alecrim MGC: Splenic hematoma in a patient with Plasmodium vivax malaria. Rev Soc Bras Med Trop 2007, 40:96-97.

42. Santana MS, Rocha MA, Arcanjo AR, Sardinha JF, Alecrim WD, Alecrim MGC: Association of methemoglobinemia and glucose-6-phosphate dehydrogenase deficiency in malaria patients treated with primaquine. Rev Soc Bras Med Trop 2007, 40:533-536.

43. Lacerda MV, Hipolito JR, Passos LN: Chronic Plasmodium vivax infection in a patient with splenomegaly and severe thrombocytopenia. Rev Soc Bras Med Trop 2008, 41:522-523.

44. Ramos WM Jr, Sardinha JF, Costa MR, Santana MS, Alecrim MG, Lacerda MV: Clinical aspects of hemolysis in patients with $P$. vivax malaria treated with primaquine, in the Brazilian Amazon. Braz J Infect Dis 2010, 14:410-412.

45. Alexandre MA, Ferreira CO, Siqueira AM, Magalhaes BL, Mourao MPG, Lacerda MVG, Alecrim MGC: Severe Plasmodium vivax Malaria, Brazilian Amazon. Emerg Infect Dis 2010, 16:1611-1614.

46. Siqueira AM, Alexandre MA, Mourao MP, Santos VS, Nagahashi-Marie SK, Alecrim MG, Lacerda MV: Severe rhabdomyolysis caused by Plasmodium vivax malaria in the Brazilian Amazon. Am J Trop Med Hyg 2010, 83:271-273.

47. Melo GC, Reyes-Lecca RC, Vitor-Silva S, Monteiro WM, Martins M, Benzecry SG, Alecrim MG, Lacerda MV: Concurrent helminthic infection protects schoolchildren with Plasmodium vivax from anemia. PLOS ONE 2010, 5:e11206.

48. Andrade BB, Reis-Filho A, Souza-Neto SM, Clarencio J, Camargo LM, Barral A, Barral-Netto M: Severe Plasmodium vivax malaria exhibits marked inflammatory imbalance. Malar J 2010, 9:13.

49. Chagas EC, Nascimento CT, Santana Filho FS, Botto-Menezes CH, MartinezEspinosa FE: Impact of malaria during pregnancy in the Amazon region. Rev Panam Salud Publica 2009, 26:203-208

50. Fragoso SC, Alexandre MA, Santos PJ, Mourao MP, Passos LN, Magalhaes BM, Siqueira AM, Lacerda MV: Hypovolaemic shock triggered by $P$. vivax infection in a patient with mild haemophilia A. Haemophilia 2011, 17:159-160.

51. Ferreira $M E$, Gomes MD, Vieira JL: Methemoglobinemia in patients with Plasmodium vivax receiving oral therapy with primaquine. Rev Soc Bras Med Trop 2011, 44:113-115.

52. Alecrim MGC, Silva VMQ, Melo MD, Araújo JR, Guerra MVF, Silva NB, Ferreira LCL, Silva EB, Alecrim WD: Splenic rupture in malarial patients from the Instituto de Medicina Tropical de Manaus [abstract]. Rev Soc Bras Med Trop 1995, 28:151

53. Kalmar EMN, Cassetari V, Machado FR, Alencar F, Kirchgatter K, Boulos M, Tapajós R: Severe malaria in patient with Plasmodium vivax infection: a case report [abstract]. Rev Soc Bras Med Trop 1998, 31:56.

54. Sardinha YF, Nunes SB, Albuquerque SRL, Marques HO, Passos LNM: Hemolytic anemia due to secondary cryoagglutinins and $P$. vivax malaria: report of two cases [abstract]. Rev Soc Bras Med Trop 1998, 31:144.

55. Victoria MB, Victoria F, Coellho AHV, Santos LO, Alecrim MGC: Thrombocytopenic purpura in patient with Plasmodium vivax malaria: case report [abstract]. Rev Soc Bras Med Trop 1998, 31:55.

56. Zumpano JF, Queiroz JN, Rocha MOC: Spontaneous splenic rupture in vivax malaria [abstract]. Rev Soc Bras Med Trop 1998, 31:46.

57. Silva SL, Santana Filho FS, Arcanjo ARL, Alecrim WD, Alecrim MGC: Clinical and hematological profile of hospitalized patients with vivax malaria and thrombocytopenia in the Fundação de Medicina Tropical do
Amazonas, from January 2007 to September 1999 [abstract]. Rev Soc Bras Med Trop 2000, 33:348.

58. Aragão PS, Alecrim MGC, Evangelista NMA, Tavares AM, Santana Filho FS, Alecrim WD: Clinical and laboratorial study on Plasmodium vivax malaria [abstract]. Rev Soc Bras Med Trop 2001, 34:341.

59. Evangelista NMA, Aragão DS, Tavares AM, Magalhães L, Alexandre MAA, Alecrim MGC, Alecrim WD: Neonatal malaria due to Plasmodium vivax in the Fundação de Medicina Tropical do Amazonas [abstract]. Rev Soc Bras Med Trop 2002, 35:344.

60. Moura ACL, Balbo BEP, Cancela ALE, Betti MH, Heneine RAD, Zumpano JF: Death due to $P$. vivax in a non-endemic area [abstract]. Rev Soc Bras Med Trop 2002, 35:369.

61. Park CHL, Ferreira CB, Bianchi CP, Fazio FS, Costa JC, Padilha ARS, Fonseca MO, Boulos M: Thrombocytopenia in patients with Plasmodium vivax malaria [abstract]. Rev Soc Bras Med Trop 2002, 35:370.

62. Viana GMC, Monteiro PS, Nascimento MDSB, Burarttini MN: Severe malaria due to P. vivax: case report [abstract]. Rev Soc Bras Med Trop 2002, 35:367.

63. Albuquerque $B C$, Couto $B B$, Moraes $T C$, Couto $S$ : The relevance of clinical and laboratorial aspects in patients with Plasmodium vivax malaria hospitalized in the Fundação de Medicina Tropical do Amazonas, 2002 [abstract]. Rev Soc Bras Med Trop 2003, 36:280.

64. Lacerda MVG, Manso MRC, Ferreira LCL, Silva FM, Santos PJT, Alecrim WD, Alecrim MGC: Patient with vivax malaria and acute lung edema in the Brazilian Amazon: case report and literature review [abstract]. Rev Soc Bras Med Trop 2003, 36:281.

65. Silva IBA, Araújo JR, Cleonardo A, Ventura AM, Pinto AY, Linonati RMF, Silva Filho M, Valente MIA, Castro JAA, Souza JM: Severe vivax malaria and noncardiogenic pulmonary edema [abstract]. Rev Soc Bras Med Trop 2003, 36:273.

66. Silva IBA, Carneiro MS, Araújo JR, von Mühler CA, Souza JM: Vivax malaria and vasculitis: case evolving with death [abstract]. Rev Soc Bras Med Trop 2004, 37:275.

67. Tavares AM, Tavares AM, Cavalcante CP: Splenic subcapsullary hematoma in patient with Plasmodium vivax malaria [abstract]. Rev Soc Bras Med Trop 2004, 37:270.

68. Penna J, Zumpano JF, Penna L, Rocha MOC: Case report: pulmonary manifestations of Plasmodium vivax malaria [abstract]. Rev Soc Bras Med Trop 2005, 38:379.

69. Mello GS, Mello Filho GB, Rodrigues DCH: Malarial coma due to Plasmodium vivax [abstract]. Rev Soc Bras Med Trop 2006, 39:106.

70. Menezes CHAB, Martinez-Espinosa FE, Ferreira LCL, Simplicio JL, Frota AC: Effects of malarial infection on the course of pregnancy and fetus in patients from the Fundação de Medicina Tropical do Amazonas [abstract]. Rev Soc Bras Med Trop 2006, 39:107.

71. Oliveira RSM, Santos VS, Lacerda MVG, Alecrim WD: Hemolysis associated to acute renal failure in an immunocompetent patient with G6PD deficiency and vivax malaria: case report with favourable evolution [abstract]. Rev Soc Bras Med Trop 2006, 39:109.

72. Bastos CJC, Mascarenhas-Batista AV, Freire M, Amorim F, Andrade M, Gomes E: Severe malaria due to Plasmodium vivax: case report [abstract]. Rev Soc Bras Med Trop 2007, 40:146.

73. Campos LRP, Mascheretti M, Brasil RA, Duarte MIS: Evaluation of splenic immune response in patient infected with Plasmodium vivax [abstract]. Rev Soc Bras Med Trop 2007, 40:141

74. Gurgel RL, Coutinho LI, Su WCS, Lacerda MVG: Clinical manifestations of congenital vivax malaria in the Western Brazilian Amazon [abstract]. Rev Soc Bras Med Trop 2007, 40:147.

75. Borzacov LMP, Cardoso GA, Siqueira GD, Cardoso LAP, Barbieri AB, Fontes CJF: Acute psychosis induced by chloroquine during vivax malaria treatment [abstract]. Rev Soc Bras Med Trop 2008, 41:221.

76. Cardoso GA, Siqueira GD, Borzacov LMP, Tristão FR, Cardoso LAP, Fontes CJF: Leukemoid reaction caused by Plasmodium vivax: case report [abstract]. Rev Soc Bras Med Trop 2008, 41:221.

77. Ohnishi MDO, Ventura AM, Linonati RMF, Mendes MM, Apolinário JHD, Souza JM: The lung in vivax malaria: case report [abstract]. Rev Soc Bras Med Trop 2008, 41:215

78. Menezes CHAB, Silva SCL, Farias LSR, Bacelar BRB, Bardaji A, Meghna D, Martinez-Espinosa FE: Prevalence of anemia and Plasmodium vivax infection in routine antenatal attention in a primary care center in the City of Manaus [abstract]. Rev Soc Bras Med Trop 2010, 43:215. 
79. Ohnishi MDO, Linonati RMF, Silva AF, Santos SEB, Ventura AM, Souza JM: Pulmonary manifestations in patients infected with Plasmodium vivax and correlation with TNF-alfa and IL-12 polymorphisms [abstract]. ReV Soc Bras Med Trop 2010, 43:84.

80. Urbaez-Brito JD: Clinical and laboratorial characteristics of human malaria and hepatitis B virus association. Master Dissertation University of Brasília, Tropical Medicine Department; 1995.

81. Alecrim MGC: Clinical aspects, resistance and parasitary polymorphism of Plasmodium vivax malaria in Manaus. PhD Thesis University of Brasília, Tropical Medicine Department; 2000.

82. Neves JJO: Malaria in Pará: study of the clinical and laboratorial picture in infections caused by Plasmodium vivax. Master Dissertation Federal University of Pará; 2002.

83. Marques HO: Hemostasis disturbances in patients with malaria. Master Dissertation Federal University of São Paulo, Hematology Department; 2004.

84. Oliveira MS: Hematological characterization of children with vivax malaria diagnosed and treated in the Fundação de Medicina Tropical do Amazonas. Master Dissertation University of the Amazonas State, Health Sciences School; 2004.

85. Silva IBA: Vivax malaria: clinical and laboratorial manifestations related to TNF-alpha. PhD Thesis Federal University of Pará; 2004.

86. Raposo CCBS: Vivax malaria in Maranhão: epidemiological and clinical aspects. Master Dissertation University of Brasília, Tropical Medicine Deprtment; 2006.

87. Pereira MSS: Study of malaria in pregnant and puerperal women in a public maternity in Manaus from 1999 to 2004. Master Dissertation Federal University of Amazonas, Health Sciences School; 2006.

88. Guerreiro NSV: Clinical and epidemiological study of Plasmodium vivax malaria in the State of Amapá. Master Dissertation Federal University of Pará; 2006.

89. Lacerda MVG: Clinical manifestations and pathogenesis of malarial thrombocytopenia. PhD Thesis University of Brasília, Tropical Medicine Department; 2007

90. Silva SBR: Evaluation of frequency and factors associated to thrombocytopenia caused by Plasmodium vivax. Master Dissertation Federal University of Mato Grosso; 2009.

91. Fragoso SCP: Study of 17 cases of autopsies from patients with the diagnosis of vivax malaria in a reference center in the Brazilian Amazon. Master Dissertation University of the Amazonas State, Health Sciences School; 2010.

92. Lança EFC: Children under 14 years with malaria admitted to Intensive Care Units in the Brazilian Amazon: a case-control study with Plasmodium vivax patients. Master Dissertation University of the Amazonas State, Health Sciences School; 2011.

93. Karunaweera ND, Wijesekera SK, Wanasekera D, Mendis KN, Carter R: The paroxysm of Plasmodium vivax malaria. Trends Parasitol 2003, 19:188-193.

94. Zimmerman PA, Mehlotra RK, Kasehagen LJ, Kazura JW: Why do we need to know more about mixed Plasmodium species infections in humans? Trends Parasitol 2004, 20:440-447.

95. Quintero JP, Siqueira AM, Tobon A, Blair S, Moreno A, Arevalo-Herrera M, Lacerda MV, Valencia SH: Malaria-related anaemia: a Latin American perspective. Mem Inst Oswaldo Cruz 2011, 106(Suppl 1):91-104.

96. Caicedo O, Ramirez O, Mourao MP, Ziadec J, Perez P, Santos JB, Quinones F, Alecrim MG, Arevalo-Herrera M, Lacerda MV, Herrera S: Comparative hematologic analysis of uncomplicated malaria in uniquely different regions of unstable transmission in Brazil and Colombia. Am J Trop Med Hyg 2009, 80:146-151.

97. Michon P, Cole-Tobian JL, Dabod E, Schoepflin S, Igu J, Susapu M, Tarongka N, Zimmerman PA, Reeder JC, Beeson JG, Schofield L, King CL, Mueller I: The risk of malarial infections and disease in Papua New Guinean children. Am J Trop Med Hyg 2007, 76:997-1008.

98. Rodriguez-Morales AJ, Sanchez E, Vargas M, Piccolo C, Colina R, Arria M: Anemia and thrombocytopenia in children with Plasmodium vivax malaria. J Trop Pediatr 2006, 52:49-51.

99. Poespoprodjo JR, Fobia W, Kenangalem E, Lampah DA, Hasanuddin A, Warikar N, Sugiarto P, Tjitra E, Anstey NM, Price RN: Vivax malaria: a major cause of morbidity in early infancy. Clin Infect Dis 2009.

100. Katsuragawa TH, Cunha RP, Souza DC, Gil LH, Cruz RB, Silva AA, Tada MS, Silva LHP: Malaria and hematological aspects among residents to be impacted by reservoirs for the Santo Antonio and Jirau Hydroelectric
Power Stations, Rondonia State, Brazil. Cad Saude Publica 2009, 25:1486-1492.

101. Ferreira MU, Silva-Nunes M, Bertolino CN, Malafronte RS, Muniz PT, Cardoso MA: Anemia and iron deficiency in school children, adolescents, and adults: a community-based study in rural Amazonia. Am J Public Health 2007, 97:237-239.

102. Cardoso MA, Ferreira MU, Camargo LM, Szarfarc SC: Anaemia, iron deficiency and malaria in a rural community in Brazilian Amazon. Eur $J$ Clin Nutr 1994, 48:326-332.

103. Wildig J, Michon P, Siba P, Mellombo M, Ura A, Mueller I, Cossart Y: Parvovirus B19 infection contributes to severe anemia in young children in Papua New Guinea. J Infect Dis 2006, 194:146-153.

104. Kochar DK, Das A, Kochar A, Middha S, Acharya J, Tanwar GS, Gupta A, Pakalapati D, Garg S, Saxena V, Subudhi AK, Boopathi PA, Sirohi P, Kochar SK: Thrombocytopenia in Plasmodium falciparum, Plasmodium vivax and mixed infection malaria: A study from Bikaner (Northwestern India). Platelets 2010, 21:623-627.

105. Lacerda MV, Mourao MP, Coelho HC, Santos JB: Thrombocytopenia in malaria: who cares? Mem Inst Oswaldo Cruz 2011, 106(Suppl 1):52-63.

106. Guidelines for the treatment of malaria. [http://whqlibdoc.who.int/ publications/2010/9789241547925_eng.pdf].

107. Takaki K, Aoki T, Akeda H, Kajiwara T, Honda S, Maeda Y, Okada K, Sawae Y: A case of Plasmodium vivax malaria with findings of DIC (abstract). Kansenshogaku Zasshi 1991, 65:488-492.

108. Lakhkar BB, Babu S, Shenoy V: DIC in vivax malaria. Indian Pediatr 1996, 33:971-972.

109. Mourao MP, Lacerda MV, Macedo VO, Santos JB: Thrombocytopenia in patients with dengue virus infection in the Brazilian Amazon. Platelets 2007, 18:605-612.

110. Santana VS, Lavezzo LC, Mondini A, Terzian AC, Bronzoni RV, Rossit AR, Machado RL, Rahal P, Nogueira MC, Nogueira ML: Concurrent Dengue and malaria in the Amazon region. Rev Soc Bras Med Trop 2010, 43:508-511.

111. Charrel RN, Brouqui $P$, Foucault C, Lamballerie X: Concurrent dengue and malaria. Emerg Infect Dis 2005, 11:1153-1154

112. WHO: Severe falciparum malaria. Trans R Soc Trop Med Hyg 2000, 94(Supp 1):S1-\$90.

113. Illamperuma C, Allen BL: Pulmonary edema due to Plasmodium vivax malaria in an American Missionary. Infection 2007, 35:374-376.

114. Pukrittayakamee S, Chantra A, Vanijanonta S, White NJ: Pulmonary oedema in vivax malaria. Trans $R$ Soc Trop Med Hyg 1998, 92:421-422.

115. Tan LK, Yacoub S, Scott S, Bhagani S, Jacobs M: Acute lung injury and other serious complications of Plasmodium vivax malaria. Lancet Infect Dis 2008, 8:449-454.

116. Anstey NM, Russell B, Yeo TW, Price RN: The pathophysiology of vivax malaria. Trends Parasitol 2009, 25:220-227.

117. Menendez C, Romagosa C, Ismail MR, Carrilho C, Saute F, Osman N, Machungo F, Bardaji A, Quinto L, Mayor A, Naniche D, Dobano C, Alonso PL, Ordi J: An autopsy study of maternal mortality in Mozambique: the contribution of infectious diseases. PLoS Med 2008, 5: e44.

118. Kochar SK, Mahajan M, Gupta RP, Middha S, Acharya J, Kochar A, Das A, Kochar DK: Acute attack of AIP (acute intermittent porphyria) with severe vivax malaria associated with convulsions: a case report. J Vector Borne Dis 2009, 46:307-309.

119. Lampah DA, Yeo TW, Hardianto SO, Tjitra E, Kenangalem E, Sugiarto $P$ Price RN, Anstey NM: Coma associated with microscopy-diagnosed plasmodium vivax: a prospective study in Papua, Indonesia. PLoS Negl Trop Dis 2011, 5:e1032.

120. Cavasini MT, Ribeiro WL, Kawamoto F, Ferreira MU: How prevalent is Plasmodium malariae in Rondonia, western Brazilian Amazon? Rev Soc Bras Med Trop 2000, 33:489-492.

121. Costa AP, Bressan CS, Pedro RS, Valls-de-Souza R, Silva S, Souza PR, Guaraldo L, Ferreira-da-Cruz MF, Daniel-Ribeiro CT, Brasil P: Delayed diagnosis of malaria in a dengue endemic area in the Brazilian extraAmazon: recent experience of a malaria surveillance unit in state of Rio de Janeiro. Rev Soc Bras Med Trop 2010, 43:571-574.

122. Kochar DK, Tanwar GS, Khatri PC, Kochar SK, Sengar GS, Gupta A, Kochar A, Middha S, Acharya J, Saxena V, Pakalapati D, Garg S, Das A: Clinical features of children hospitalized with malaria-a study from Bikaner, northwest India. Am J Trop Med Hyg 2010, 83:981-989. 
123. Kochar DK, Das A, Kochar SK, Saxena V, Sirohi P, Garg S, Kochar A, Khatri MP, Gupta V: Severe Plasmodium vivax malaria: a report on serial cases from Bikaner in northwestern India. Am J Trop Med Hyg 2009, 80:194-198.

124. Kochar DK, Singh P, Agarwal P, Kochar SK, Pokharna R, Sareen PK: Malarial hepatitis. J Assoc Physicians India 2003, 51:1069-1072

125. Khan FY, El-Hiday AH: Acute acalculous cholecystitis complicating an imported case of mixed malaria caused by Plasmodium falciparum and Plasmodium vivax. Int J Infect Dis 2010, 14(Suppl 3):e217-219.

126. Kumar A, Katiyar GP: Mixed infection with Plasmodium vivax and Salmonella typhi in an infant. Indian Pediatr 1995, 32:243-244.

127. Piyaphanee $W$, Issarachaikul R, Soontarach P, Silachamroon U: Concurrent salmonella bacteremia in P. vivax infection-a report of 2 cases at the Hospital for Tropical Diseases, Thailand. Southeast Asian J Trop Med Public Health 2007, 38:616-618.

128. Fonseca JC: Natural history of chronic hepatitis B. Rev Soc Bras Med Trop 2007, 40:672-677

129. Lacerda MV, Mourao MP, Santos PJ, Alecrim MG: Algid malaria: a syndromic diagnosis. Rev Soc Bras Med Trop 2009, 42:79-81.

130. Stoppacher R, Adams SP: Malaria deaths in the United States: case report and review of deaths, 1979-1998. J Forensic Sci 2003, 48:404-408.

131. Bassat Q, Guinovart C, Sigauque B, Mandomando I, Aide P, Sacarlal J, Nhampossa T, Bardaji A, Morais L, Machevo S, Letang E, Macete E, Aponte JJ, Roca A, Menendez C, Alonso PL: Severe malaria and concomitant bacteraemia in children admitted to a rural Mozambican hospital. Trop Med Int Health 2009, 14:1011-1019.

132. Song JY, Park CW, Jo YM, Kim JY, Kim JH, Yoon HJ, Kim CH, Lim CS, Cheong HJ, Kim WJ: Two cases of Plasmodium vivax malaria with the clinical picture resembling toxic shock. Am J Trop Med Hyg 2007, 77:609-611.

133. Anstey NM, Handojo T, Pain MC, Kenangalem E, Tjitra E, Price RN, Maguire GP: Lung injury in vivax malaria: pathophysiological evidence for pulmonary vascular sequestration and posttreatment alveolarcapillary inflammation. J Infect Dis 2007, 195:589-596.

134. Carvalho BO, Lopes SC, Nogueira PA, Orlandi PP, Bargieri DY, Blanco YC, Mamoni R, Leite JA, Rodrigues MM, Soares IS, Oliveira TR, Wunderlich G, Lacerda MV, Del Portillo HA, Araujo MO, Russell B, Suwanarusk R, Snounou G, Renia L, Costa FT: On the Cytoadhesion of Plasmodium vivaxInfected Erythrocytes. J Infect Dis 2010, 202:638-647.

135. Echeverri M, Tobon A, Alvarez G, Carmona J, Blair S: Clinical and laboratory findings of Plasmodium vivax malaria in Colombia, 2001. Rev Inst Med Trop São Paulo 2003, 45:29-34.

136. Nosten F, McGready R, Simpson JA, Thwai KL, Balkan S, Cho T, Hkirijaroen L, Looareesuwan S, White NJ: Effects of Plasmodium vivax malaria in pregnancy. Lancet 1999, 354:546-549.

137. Poespoprodjo JR, Fobia W, Kenangalem E, Lampah DA, Warikar N, Seal A, McGready R, Sugiarto P, Tijtra E, Anstey NM, Price RN: Adverse pregnancy outcomes in an area where multidrug-resistant Plasmodium vivax and Plasmodium falciparum infections are endemic. Clin Infect Dis 2008, 46:1374-1381

138. Martinez-Espinosa FE, Daniel-Ribeiro CT, Alecrim WD: Malaria during pregnancy in a reference centre from the Brazilian Amazon: unexpected increase in the frequency of Plasmodium falciparum infections. Mem Inst Oswaldo Cruz 2004, 99:19-21.

139. Poels PJ, Dolmans WM, Gabreels FJ: Rhabdomyolysis associated with malaria tertiana in a patient with myoadenylate deaminase deficiency. Trop Geogr Med 1993, 45:83-86.

140. Hamel CT, Blum J, Harder F, Kocher T: Nonoperative treatment of splenic rupture in malaria tropica: review of literature and case report. Acta Trop 2002, 82:1-5.

141. Lewallen S, Harding SP, Ajewole J, Schulenburg WE, Molyneux ME, Marsh K, Usen S, White NJ, Taylor TE: A review of the spectrum of clinical ocular fundus findings in $P$. falciparum malaria in African children with a proposed classification and grading system. Trans $R$ Soc Trop Med Hyg 1999, 93:619-622.

142. Lee $\mathrm{JH}$, Chin HS, Chung MH, Moon YS: Retinal Hemorrhage in Plasmodium vivax Malaria. Am J Trop Med Hyg 2010, 82:219-222.

143. Vitor-Silva S, Reyes-Lecca RC, Pinheiro TR, Lacerda MV: Malaria is associated with poor school performance in an endemic area of the Brazilian Amazon. Malar J 2009, 8:230.

144. Williams TN, Maitland K, Phelps L, Bennett S, Peto TE, Viji J, Timothy R, Clegg JB, Weatherall DJ, Bowden DK: Plasmodium vivax: a cause of malnutrition in young children. QJM 1997, 90:751-757.
145. Pereira PC, Meira DA, Curi PR, Souza N, Burini RC: The malarial impact on the nutritional status of Amazonian adult subjects. Rev Inst Med Trop Sao Paulo 1995, 37:19-24.

146. Ventura AM, Pinto AY, Silva RS, Calvosa VS, Silva Filho MG, Souza JM: Plasmodium vivax malaria in children and adolescents - epidemiological, clinical and laboratory features. J Pediatr (Rio J) 1999, 75:187-194.

147. Silamut K, White NJ: Relation of the stage of parasite development in the peripheral blood to prognosis in severe falciparum malaria. Trans $R$ Soc Trop Med Hyg 1993, 87:436-443.

148. Andrade BB, Reis-Filho A, Souza-Neto SM, Raffaele-Netto I, Camargo LM, Barral A, Barral-Netto M: Plasma superoxide dismutase-1 as a surrogate marker of vivax malaria severity. PLoS Negl Trop Dis 2010, 4:e650.

149. Santana MS, Lacerda MVG, Barbosa MGV, Alecrim WD, Alecrim MGC Glucose-6-phosphate dehydrogenase deficiency in an endemic area for malaria in Manaus: a cross-sectional survey in the Brazilian Amazon. PLoS ONE 2009, 4:e5259.

150. Leslie T, Briceno M, Mayan I, Mohammed N, Klinkenberg E, Sibley CH, Whitty CJ, Rowland M: The impact of phenotypic and genotypic G6PD deficiency on risk of Plasmodium vivax infection: a case-control study amongst Afghan refugees in Pakistan. PLoS Med 2010, 7:e1000283.

151. Guindo A, Fairhurst RM, Doumbo OK, Wellems TE, Diallo DA: X-linked G6PD deficiency protects hemizygous males but not heterozygous females against severe malaria. PLoS Med 2007, 4:e66.

152. Cavasini CE, de Mattos LC, Couto AA, Couto VS, Gollino Y, Moretti LJ, Bonini-Domingos CR, Rossit AR, Castilho L, Machado RL: Duffy blood group gene polymorphisms among malaria vivax patients in four areas of the Brazilian Amazon region. Malar J 2007, 6:167.

153. Cavasini CE, Mattos LC, Couto AA, Bonini-Domingos CR, Valencia SH, Neiras WC, Alves RT, Rossit AR, Castilho L, Machado RL: Plasmodium vivax infection among Duffy antigen-negative individuals from the Brazilian Amazon region: an exception? Trans R Soc Trop Med Hyg 2007, 101:1042-1044

154. Albuquerque SR, Cavalcante F, de O, Sanguino EC, Tezza L, Chacon F, Castilho L, dos Santos MC: FY polymorphisms and vivax malaria in inhabitants of Amazonas State, Brazil. Parasitol Res 2010, 106:1049-1053.

155. Costa FT, Lopes SC, Ferrer M, Leite JA, Martin-Jaular L, Bernabeu M, Nogueira PA, Mourao MP, Fernandez-Becerra C, Lacerda MV, Portillo HD: On cytoadhesion of Plasmodium vivax: raison d'etre? Mem Inst Oswaldo Cruz 2011, 106(Suppl 1):79-84.

156. Campos FM, Franklin BS, Teixeira-Carvalho A, Filho AL, de Paula SC, Fontes CJ, Brito CF, Carvalho LH: Augmented plasma microparticles during acute Plasmodium vivax infection. Malar J 2010, 9:327.

157. Andrade BB, Araujo-Santos T, Luz NF, Khouri R, Bozza MT, Camargo LM, Barral A, Borges VM, Barral-Netto M: Heme impairs prostaglandin E2 and TGF-beta production by human mononuclear cells via $\mathrm{Cu} / \mathrm{Zn}$ superoxide dismutase: insight into the pathogenesis of severe malaria. J Immunol 2010, 185:1196-1204.

158. Erel O, Vural H, Aksoy N, Aslan G, Ulukanligil M: Oxidative stress of platelets and thrombocytopenia in patients with vivax malaria. Clin Biochem 2001, 34:341-344.

159. Araujo CF, Lacerda MV, Abdalla DS, Lima ES: The role of platelet and plasma markers of antioxidant status and oxidative stress in thrombocytopenia among patients with vivax malaria. Mem Inst Oswaldo Cruz 2008, 103:517-521.

160. Grynberg P, Fernandes Fontes CJ, Martins Braga E: Association between particular polymorphic residues on apical membrane antigen 1 (AMA-1) and platelet levels in patients with vivax malaria. Clin Microbiol Infect 2007.

161. Fernandes AA, Carvalho LJ, Zanini GM, Ventura AM, Souza JM, Cotias PM, Silva-Filho IL, Daniel-Ribeiro CT: Similar cytokine responses and degrees of anemia in patients with Plasmodium falciparum and Plasmodium vivax infections in the Brazilian Amazon region. Clin Vaccine Immunol 2008, 15:650-658.

162. Wickramasinghe SN, Abdalla SH: Blood and bone marrow changes in malaria. Baillieres Best Pract Res Clin Haematol 2000, 13:277-299.

163. Fernandez-Becerra C, Yamamoto MM, Vencio RZ, Lacerda M, RosanasUrgell A, Del Portillo HA: Plasmodium vivax and the importance of the subtelomeric multigene vir superfamily. Trends Parasitol 2008, 25:44-51.

164. Santos-Ciminera PD, Alecrim MD, Roberts DR, Quinnan GV Jr: Molecular epidemiology of Plasmodium vivax in the State of Amazonas, Brazil. Acta Trop 2007 
165. Bussaratid V, Walsh DS, Wilairatana P, Krudsood S, Silachamroon U, Looareesuwan S: Frequency of pruritus in Plasmodium vivax malaria patients treated with chloroquine in Thailand. Trop Doct 2000, 30:211-214.

166. Sahoo S, Kumar M, Sinha VK: Chloroquine-induced recurrent psychosis. Am J Ther 2007, 14:406-407.

167. Katsuragawa TH, Gil LHS, Stabile RG, Pires MG, Bonini-Domingos CR: Incidence evaluation of Glucose-6-Phosphate Dehydrogenase and hematological profile in Rondônia. Rev Bras Hematol Hemoter 2004, 26:268-273.

168. Silva MC, Santos EB, Costal EG, Filho MG, Guerreiro JF, Povoa MM: Clinical and laboratorial alterations in Plasmodium vivax malaria patients and glucose-6-phosphate dehydrogenase deficiency treated with primaquine at $0.50 \mathrm{mg} / \mathrm{kg} /$ day. Rev Soc Bras Med Trop 2004, 37:215-217.

169. Walsh DS, Wilairatana P, Tang DB, Heppner DG Jr, Brewer TG, Krudsood S, Silachamroon U, Phumratanaprapin W, Siriyanonda D, Looareesuwan S: Randomized trial of 3-dose regimens of tafenoquine (WR238605) versus low-dose primaquine for preventing Plasmodium vivax malaria relapse. Clin Infect Dis 2004, 39:1095-1103.

170. Price RN, Douglas NM, Anstey NM: New developments in Plasmodium vivax malaria: severe disease and the rise of chloroquine resistance. Curr Opin Infect Dis 2009, 22:430-435.

171. Alecrim MG, Alecrim W, Macedo V: Plasmodium vivax resistance to chloroquine (R2) and mefloquine (R3) in Brazilian Amazon region. Rev Soc Bras Med Trop 1999, 32:67-68.

172. Santana Filho FS, Arcanjo AR, Chehuan YM, Costa MR, Martinez-Espinosa FE, Vieira JL, Barbosa MG, Alecrim WD, Alecrim MG: Chloroquine-resistant Plasmodium vivax, Brazilian Amazon. Emerg Infect Dis 2007, 13:1125-1126.

173. Orjuela-Sanchez P, Santana Filho FS, Machado-Lima A, Chehuan YF, Costa MR, Alecrim MD, Del Portillo HA: Analysis of single-nucleotide polymorphisms in the crt-o and mdr1 genes of Plasmodium vivax among chloroquine resistant isolates from the Brazilian Amazon region. Antimicrob Agents Chemother 2009.

174. Fernandez-Becerra C, Pinazo MJ, Gonzalez A, Alonso PL, Del Portillo HA, Gascon J: Increased expression levels of the pvcrt-o and pvmdr1 genes in a patient with severe Plasmodium vivax malaria. Malar J 2009, 8:55.

175. Douglas NM, Anstey NM, Angus BJ, Nosten F, Price RN: Artemisinin combination therapy for vivax malaria. Lancet Infect Dis 2010, 10:405-416.

176. Pessoa SB: Parasitologia Médica. Rio de Janeiro: Guanabara-Koogan; 11 1967.

177. Alves FP, Durlacher RR, Menezes MJ, Krieger H, Silva LH, Camargo EP: High prevalence of asymptomatic Plasmodium vivax and Plasmodium falciparum infections in native Amazonian populations. Am J Trop Med Hyg 2002, 66:641-648.

178. Halstead SB: Dengue. Curr Opin Infect Dis 2002, 15:471-476.

doi:10.1186/1475-2875-11-12

Cite this article as: Lacerda et al:: Understanding the clinical spectrum of complicated Plasmodium vivax malaria: a systematic review on the contributions of the Brazilian literature. Malaria Journal 2012 11:12.

\section{Submit your next manuscript to BioMed Central and take full advantage of:}

- Convenient online submission

- Thorough peer review

- No space constraints or color figure charges

- Immediate publication on acceptance

- Inclusion in PubMed, CAS, Scopus and Google Scholar

- Research which is freely available for redistribution

Submit your manuscript at www.biomedcentral.com/submit
Biomed Central 